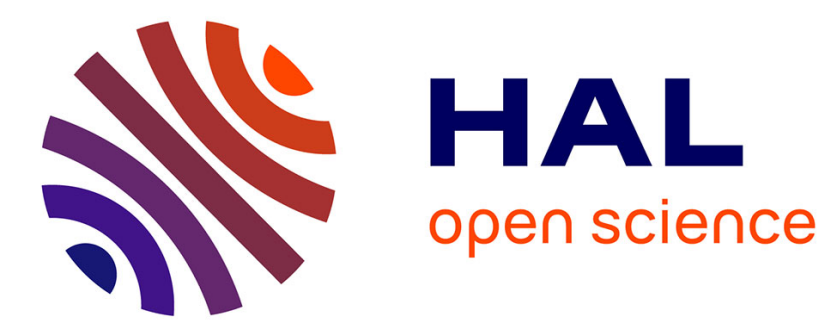

\title{
Beyond the sea... The Neolithic transition in the southwest of France
}

\author{
Thomas Perrin, Claire Manen, Nicolas Valdeyron, Jean Guilaine
}

\section{To cite this version:}

Thomas Perrin, Claire Manen, Nicolas Valdeyron, Jean Guilaine. Beyond the sea... The Neolithic transition in the southwest of France. Quaternary International, 2017, 470, pp.318 - 332. 10.1016/j.quaint.2017.05.027 . hal-01593272

\section{HAL Id: hal-01593272 \\ https://hal.science/hal-01593272}

Submitted on 1 Nov 2018

HAL is a multi-disciplinary open access archive for the deposit and dissemination of scientific research documents, whether they are published or not. The documents may come from teaching and research institutions in France or abroad, or from public or private research centers.
L'archive ouverte pluridisciplinaire HAL, est destinée au dépôt et à la diffusion de documents scientifiques de niveau recherche, publiés ou non, émanant des établissements d'enseignement et de recherche français ou étrangers, des laboratoires publics ou privés. 


\title{
Beyond the sea... The Neolithic transition in the southwest of France
}

\author{
Thomas Perrin*, Claire Manen, Nicolas Valdeyron, Jean Guilaine \\ CNRS, UMR 5608 TRACES, Université de Toulouse 2 Jean Jaurès, Maison de la Recherche, 5, allée Antonio-Machado, F-31058, Toulouse cedex 9, France
}

\section{A R T I C L E I N F O}

\section{Article history:}

Received 31 January 2017

Received in revised form

30 April 2017

Accepted 16 May 2017

Available online 26 May 2017

\section{Keywords:}

Second Mesolithic

Early Neolithic

Neolithic spread

Southern France

Mediterranean hinterland

Taphonomy

Radiocarbon

Cuzoul de Gramat

Roquemissou

\begin{abstract}
A B S T R A C T
The neolithisation of the South of France occurred in several stages and involved different processes. During the first half of the sixth millennium cal. BC, the first Neolithic installations were sporadic settlements of pioneering groups from Italy. During the second stage, several centuries later, many Neolithic sites appeared, first of all, along the Mediterranean shore, and then later further inland. The settlement of the hinterlands, particularly in the Southwest of France, led to a relatively marked recomposition of the technical and economic framework of Neolithic societies, which has at times been attributed to interactions with groups of hunters. However, the critical examination of the available data, supported by new radiocarbon dates, shows that very few sites used up until now to discuss this scenario can actually be considered to be reliable. Two new ongoing excavations illustrate the complexity of the sedimentary and taphonomic processes of multi-phased archaeological infillings and provide more reliable new data. This dual approach, combining the reassessment of former data with new primary evidence, brings to light the overly binary emphasis on the traditional division between Mesolithic hunters and Neolithic farmers; as the human groups involved in the neolithisation process can represent a number of intermediary situations.
\end{abstract}

() 2017 Elsevier Ltd and INQUA. All rights reserved.

\section{Introduction}

From a historical point of view, the Neolithic transition is a fundamental period during which Man modifies his relationships with the environment in diverse ways, to establish an economy based on animal husbandry and farming. In archaeology, approaches to this "neolithisation" process are very varied. In Europe, the study of neolithisation involves the analysis of diffusion vectors (cultural diffusion through societies of native hunter-gatherers vs demic diffusion through the migration of populations from the Near East, where most of the domestic animal and plant species come from); but also an approach focusing on the rhythms of emergence of techno-economic Neolithic innovations. Research carried out during the 1980s outlining a European Neolithic developing from east to west following a regular rhythm (Ammerman and Cavalli-Sforza, 1984) has been supplanted by more recent work showing that the general diffusion dynamics of the Neolithic economy in Europe correspond to an arrhythmic model (Guilaine, 2013).

\footnotetext{
* Corresponding author.

E-mail addresses: tperrin@univ-tlse2.fr (T. Perrin), claire.manen@univ-tlse2.fr (C. Manen), valdeyro@univ-tlse2.fr (N. Valdeyron), guilaine.jean@orange.fr (J. Guilaine).
}

In this context, recent research in the western Mediterranean Basin consistently shows the complexity and the polymorphism of the neolithisation process underlying the multiform cultural landscape (Binder, 2013; Manen, 2014; Bernabeu Aubán et al., 2015). In this zone, the French Mediterranean shoreline was settled at an early stage, as shown by the emergence of agropastoral practices at around $5750 \mathrm{cal}$. BC. These data come from different archaeological sites but also from indirect evidence of anthropization (in particular the presence of pollen from cereals in some sedimentary sequences; Ambert et al., 1995; Puertas, 1999). Among the archaeological sites, the two sites of Peiro Signado and Pont de Roque-Haute, at Portiragnes in the Hérault, clearly demonstrate that the very first phase of neolithisation is linked to the settlement of populations of Italian origin (Guilaine et al., 2007; Briois and Manen, 2009; Bernabeu Aubán et al., in press). They thus provide evidence of a new historic episode; that is, the implantation of small pioneering groups during the first half of the sixth millennium cal. BC, probably from the Italian Peninsula. These Neolithic settlers kept the same way of life as in their original region, based on Ceramica impressa, but they also adapted to the regional environmental setting and used the diversity of coastal resources. These pioneering sites illustrate a wider Western Mediterranean trend probably based on processes of rapid to longdistance marine travels, but with only a slight transformation of 
technical and economic traditions (Zilhão, 2001; Mazurié de Keroualin, 2003; Manen and Convertini, 2012). After a certain lapse of time, a new cultural and economic complex develops at around 5400 cal. BC; the Cardial complex, which may not have any direct link with these pioneering sites (Guilaine and Manen, 2007). We observe at that time a major geographic expansion of Neolithic techno-economic developments. Alongside this expansion and the exploitation of new ecosystems, some of the technical and cultural aspects of these societies appear to be reconfigured. Comparable, but recomposed cultural and economic systems then develop, separated by a relatively short interval of time and slight geographical distances. In light of this, the main challenge for current research is to understand the mechanisms underlying these recompositions. Must we identify the characteristics of the environment as driving forces in the adaptation and evolution of skills? What is the role of social endogenous or exogenous dynamics in cultural developments? In this paper, we will explore the continental extension of Mediterranean neolithisation in the light of new results obtained as part of two excavation programmes and a collective research programme.

\section{The chronological and regional framework}

In the South of France, the Early Neolithic presents real chronological complexity, as it develops over more than a millennium, from the first steps of the agro-pastoral economy, which emerges at the beginning of the sixth millennium cal. BC, to the phases of development and consolidation of the agro-pastoral influence and socio-economic change from the middle of the fifth millennium cal. BC. Several horizons can be identified, with reference in particular to absolute chronological data and the periodization of material productions, in the Rhone Valley (Perrin, 2008, 2013), Provence (Binder and Sénépart, 2010) or in Languedoc (Manen and Guilaine, 2010).

If, first of all, we only take account of the absolute dates, ${ }^{1}$ with no presuppositions as to the order of the diverse cultural facies, it is possible to identify several stages in the development of agropastoral societies. We initially showed that a global analysis (i.e., using the sum of probabilities of the calibrated dates) of the reliable dates retained for the whole of the Early Neolithic in the South of France revealed several peaks (Manen and Sabatier, 2003; Binder and Sénépart, 2010; Perrin, 2013; Perrin et al., 2014). However, these have no historical grounding in terms of population density (as shown for instance by Crombé and Robinson, 2014) or even in terms of chronological phases, as they only reflect the oscillations of the calibration curve (Fig. 1). In order to create chronological groups more objectively, relying less on the irregularities of the calibration curve, we undertook an automatic classification of the average value of each of the calibrated dates, which led to the identification of four main groups (Fig. 1, bottom). The absence of direct correlation between the irregularities of the calibration curve and the range of these groups is an argument in favour of their relevance. A first group encompasses the nine oldest dates, situated between 5850 and 5650 cal. BC (stage qualified as "Early Neolithic 1 " in Perrin, 2008). The second group includes 35 dates spread out between 5600 and 5250 cal. BC (or "Early Neolithic 2", ibid.). The third comprises 71 dates ranging between 5250 and 4950 cal. BC (or "Early Neolithic 3", ibid.). The last set includes 38 dates between

\footnotetext{
1 This work is based on the radiocarbon data published in the studies cited in the bibliography here and also over one hundred new AMS dates that have been carried out in a collective project (PROCOME Project cf. infra). These new data are in the process of being published. These radiocarbon data have been audited with the protocol described in Manen, 2014).
}

4950 and $4550 \mathrm{cal}$. BC, and corresponds to an ultimate transition stage with the Middle Neolithic, or the first phase of the Middle Neolithic.

If we then correlate these chronological phases with all of the cultural data, we can propose the following scenario for the emergence and development of agro-pastoral societies in the South of France:

- Stage 1: implementation of the production economy (58505650 cal. BC). In the South of France (Binder, 2013; Manen, 2014), this initial phase is characterized by the implantation of small groups of settlers from the Italian Peninsula (Impressa culture) at the beginning of the sixth millennium cal. BC. At the sites of Peiro Signado and Pont de Roque-Haute (Guilaine et al., 2007; Briois and Manen, 2009), food resources were based on specialized caprine breeding and cereal culture (mainly emmer wheat and Einkorn). Links with the Italian sphere are confirmed by the analysis of the ceramic and lithic systems (namely pressure blade debitage), but also by the presence of obsidian from Palmarolla and Sardinia. For now, the impact of these groups seems to be confined to the coastline.

- Stage 2: during a second period (5400-5250 cal. BC), the Cardial complex develops and becomes the vector of Neolithisation in a wider geographic range (Binder, 2013). New ecosystems are taken over, alongside a diversification of food acquisition systems (Vigne, 2007), which include domestic meat resources (mainly sheep and goats), but also wild animals (wild boar, red deer ...) and the cultivation of naked wheat and barley. In the same way, the diverse settled environments (plains, coastal zones but also plateaus and garrigues) and types of sites (openair sites, caves, rock shelters) point to a reorganization of the socio-economic systems. The acquisition and circulation networks of mineral raw materials are also transformed and point to more regional spheres.

- Stage 3: consolidation of the production economy (52504950 cal. BC). Evidence of Neolithic settlements multiplies during this chronological period and extends over very varied geographic domains (Manen, 2014). This far-reaching geographical range also includes the exploitation of mountainous zones (Massif central, Alps, Jura). From a chronocultural viewpoint, in the Southwest of France, this phase corresponds to the full expansion of what is known as the Epicardial (Perrin et al., 2014).

- Stage 4: end of the neolithisation process and territorial attachment (4900-4500 cal. BC). This last stage of the Early Neolithic represents the final phase of the neolithisation process and some aspects of the material culture point to narrower territories (in particular raw material management), whereas the diffusion of certain traits over long distances also seems to emerge (Manen and Guilaine, 2010).

The transition processes leading to the cultural rupture in the middle of the fifth millennium have yet to be defined.

The altitudinal distribution or the distance of Early Neolithic sites from the sea based on the chronology clearly shows that settlements were first of all coastal, then progressively spread inland from 5400 cal. BC (Fig. 2). Then this taking over of new territories seems to slow down around 5300-5100, followed by a new expansion phase from $5100 \mathrm{cal}$. BC. Here, we will focus mainly on these last stages in order to characterize and understand the origin of the variability of the cultural expressions of the first farming communities during their expansion into new territories, the Mediterranean hinterland, and in particular in the Southwest of France. 
Calibrated date (calBC)

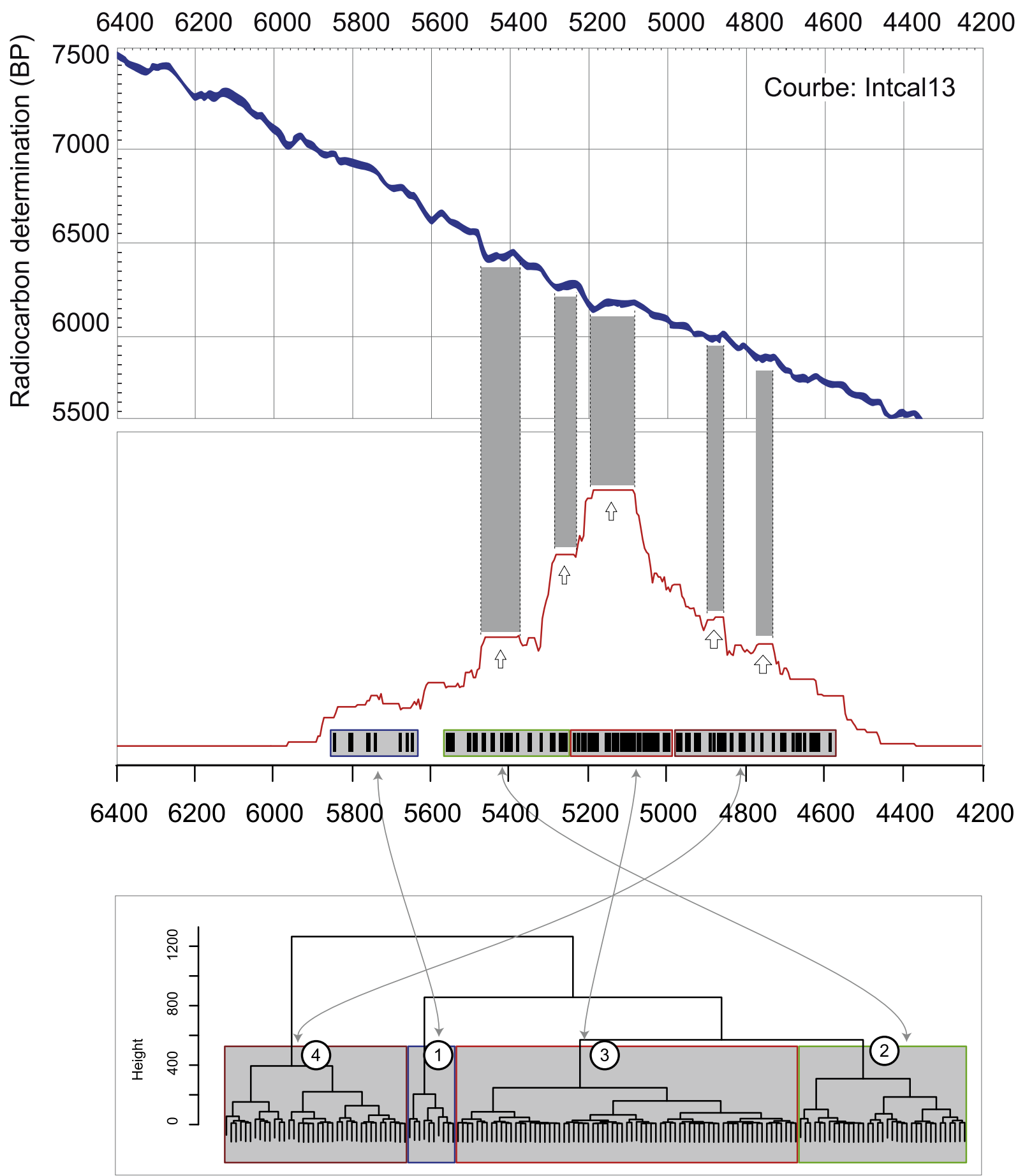

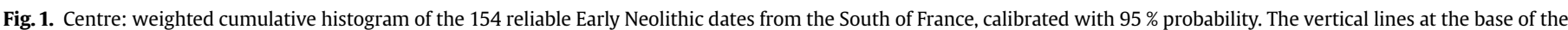

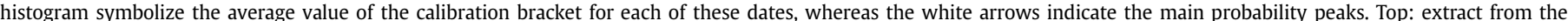

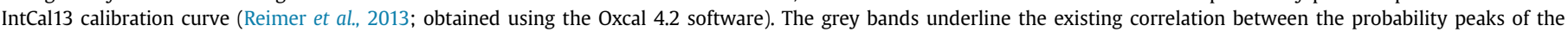

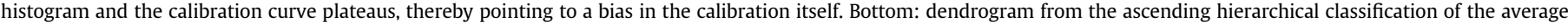
value of the calibrated dates. Four main sets can be identified defining four chronological stages in the Early Neolithic in the South of France.

\section{Focus on the Mediterranean hinterland}

\subsection{Regional setting}

As stated above, the spread of the Neolithic economy is correlated with a recomposition of the economic and cultural technical systems. In Mediterranean hinterland regions (i.e. SouthWest of Massif central, Aquitain basin, Northern Pyrenees, Fig. 3), the specific cultural expressions of sixth millennium communities were interpreted for a long time as the result of interactions 


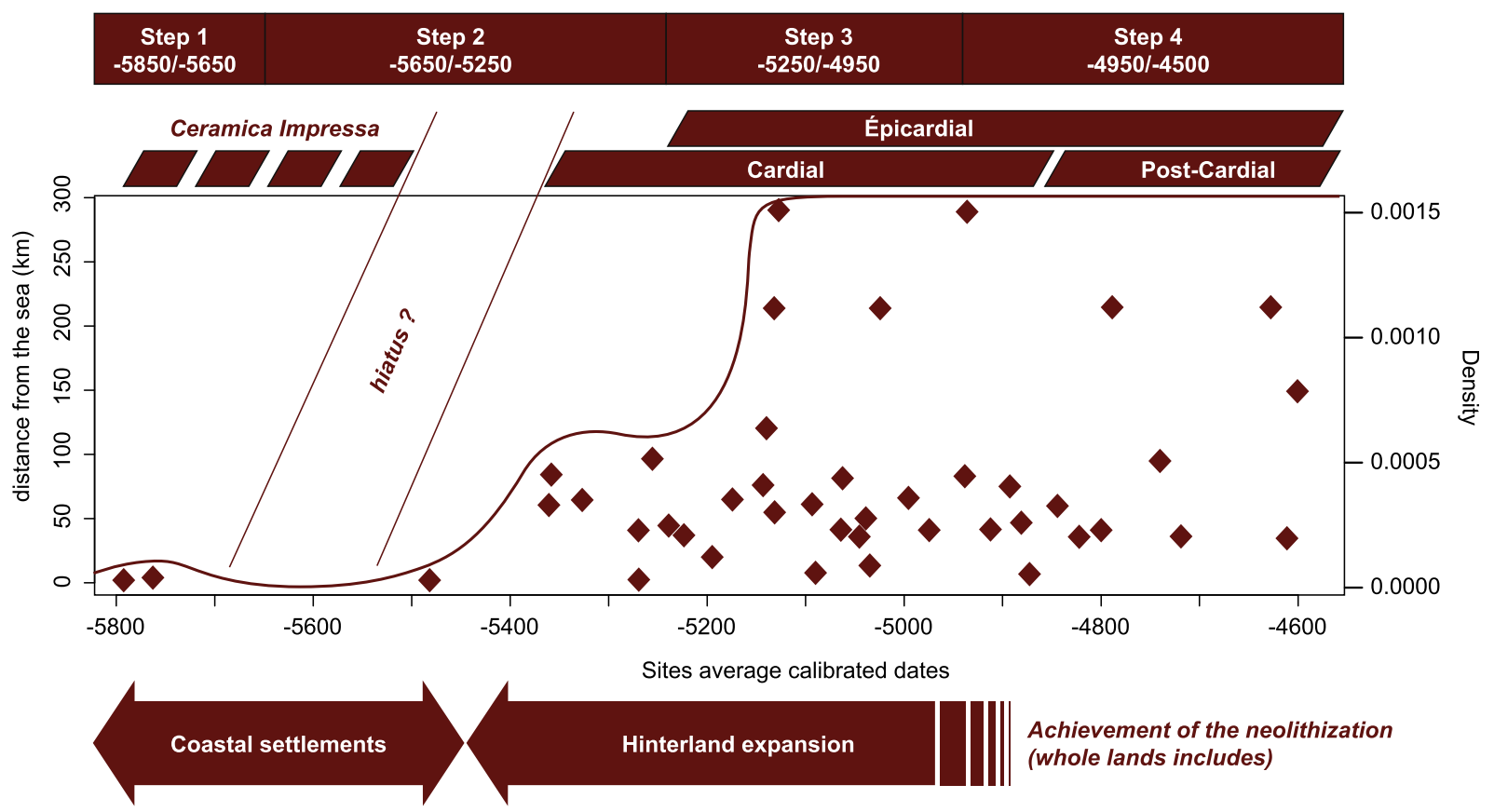

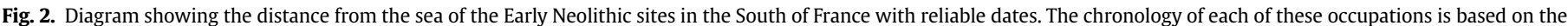

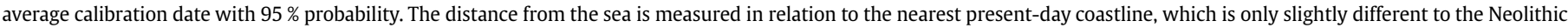
coastline (several kilometres at the most in the Gulf of Lion).

between the last groups of hunter-gatherers and the first agropastors (for example Roussot-Larroque, 1987; Vaquer, 1990; Van Willigen, 2004). In this way, the Roucadourian was created, defined as a novel expression of the Early Neolithic (RoussotLarroque, 1985). However, all the recent works have shown that these proposals were based on tenuous and contestable data, related mainly to poorly understood or poorly excavated stratigraphic contexts. The notion of the Roucadourian must therefore be definitively abandoned as it comprises very diverse facets from the seventh and sixth millennia cal. BC (Marchand, 1999). However, although we know that cultural expressions of the communities at the beginning of the Neolithic in the hinterland are at least partly genetically linked to those of the Mediterranean shore, we still cannot characterize them accurately. Often the mention of the presence of coarse pottery, or of cutting or trapezoid arrow heads, is the only classification. A rather similar observation can be made for the Recent and Late Mesolithic, combined under the label Second Mesolithic (Marchand, 1999). Up until recently, almost all the authors agreed that the Castelnovian, which is the main expression of the Second Mesolithic in the South of France, remained confined to the Languedoc plain for its extension to the West. In Aquitaine and Western Languedoc, the Second Mesolithic is characterized by a specific group, called Cuzoul-Gazel, with no laminar debitage or trapezes (Barbaza, 1993). However, the homogeneity of this group was soon called into question (Valdeyron, 2000). The lack of consistency of the sites theoretically attributed to the Cuzoul-Gazel, in terms of material production and the chronology (Perrin, 2013), shows that this notion must also now be definitively abandoned. Furthermore, the reassessment of several series from to the northeasterly extremity of the Pyrenees, shows the presence of industry that could be confidently attributed to the Castelnovian elsewhere. Ultimately, the chronocultural situation during the Second Mesolithic in this south-western quarter of France remains unclear, on account of early, imprecise excavations in contexts with multiple occupations and complex sedimentary processes.
This poor definition of the background of the Second Mesolithic and the Early Neolithic clearly prejudices the identification of potential cases of interactions between the last hunters and agropastors. These hypotheses are generally based on several specific material or economic elements "discovered" in settings described as Mesolithic or Neolithic. Let us cite, for example, the alleged presence of domestic animal remains in Mesolithic levels, such as at Gazel or Dourgne (Geddès, 1993), the concomitant presence of Mesolithic industries and Neolithic pottery, such as in the exRoucadourian, or the presence of typically Neolithic armatures or in any case, interpreted as such - such as the "Montclus arrowheads" in Mesolithic contexts, as for example at Grande-Rivoire (Nicod et al., 2012) or Cuzoul de Gramat (Valdeyron et al., 2013). In reality, the identification of such interactions must rely on more complete and more all-encompassing methods, and extend beyond mere emphasis on a particular attribute. At the scale of the archaeological site, it is essential to take account of geoarchaeological data in order to approach the question of the coherency of the stratigraphic units: can the level in question be considered to be reliable or can it result from the compression of multiple occupation levels in a single stratigraphic unit as a consequence of post-depositional effects (Zilhão, 1993; Guilaine et al., 1993; Bernabeu Aubán et al., 2001; Biagi, 2003; Berger et al., 2014; Defranould et al., 2017)? At a regional level, it is also essential to take account of chronological and geographic distances between the different sites, but this is only rarely established. We have shown that, at least in the current state of knowledge, potential zones of contact only existed in specific places, on the geographic fringes of the main Mediterranean Early Neolithic expansion (Perrin, 2013).

A significant renewal of primary data is thus essential in order to advance our understanding of the processes and dynamics involved in this geographic area. This necessitates a critical review of the currently available data, but also new excavations at key sites likely to provide new answers. 


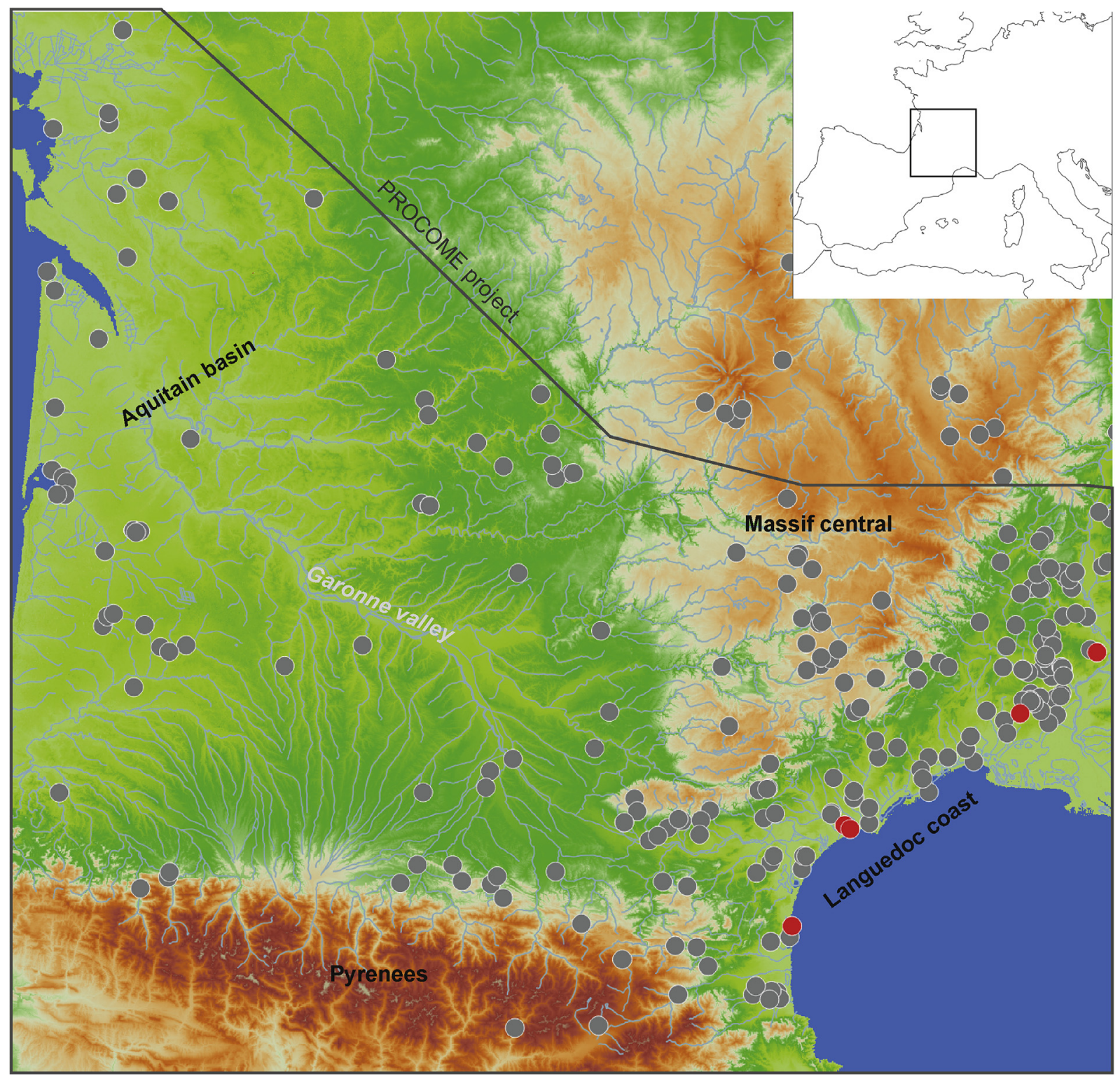

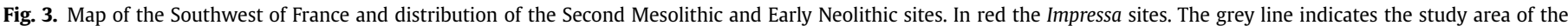
PROCOME project. (For interpretation of the references to colour in this figure legend, the reader is referred to the web version of this article.)

\subsection{Auditing the database}

As part of a research programme focusing on the continental extension of Mediterranean neolithisation ${ }^{2}$ and new excavations, we reviewed the data from the Southwest of France, from the Pyrenees to the Massif Central and from the Mediterranean shores to the Atlantic (Fig. 3). This documentary overview includes markers or remains of settlements dated to the Second Mesolithic or the Early Neolithic, roughly from the sixth and fifth millennia cal. BC. This information was brought together in a geo-referenced database and the archaeological sequences were ranked according to four confidence ratings based on the reliability of the excavation, the understanding of the chrono-stratigraphic contexts and the quality of the collected corpuses:

\footnotetext{
${ }^{2}$ PROCOME Project (ANR-13-CULT-0001-01) directed by C. Manen: http://www.
} anrprocome.com/.
- Top Priority Settlement (TPS): excellent confidence rating, recent excavation, "large" excavated surface, large diversified corpus.

- Priority Settlement (PS): good confidence rating, controlled context in spite of older excavation methods and/or reduced corpus (absence of certain categories of remains).

- Secondary Settlement (SS): average confidence rating, contextual excavation data requiring verification or corpus issued from a diagnostic archaeological operation (or survey) and not from a real and extensive excavation.

- Point settlement (S): poor confidence rating, no stratigraphic context, early excavation, collection of remains.

All in all, 244 Second Mesolithic and Early Neolithic sites are currently known in the geographic area under consideration in the PROCOME project, but only $14 \%$ of them correspond to the first two categories (Fig. 4). These sites show disparate geographic distribution and a separation between the Mediterranean area and the 

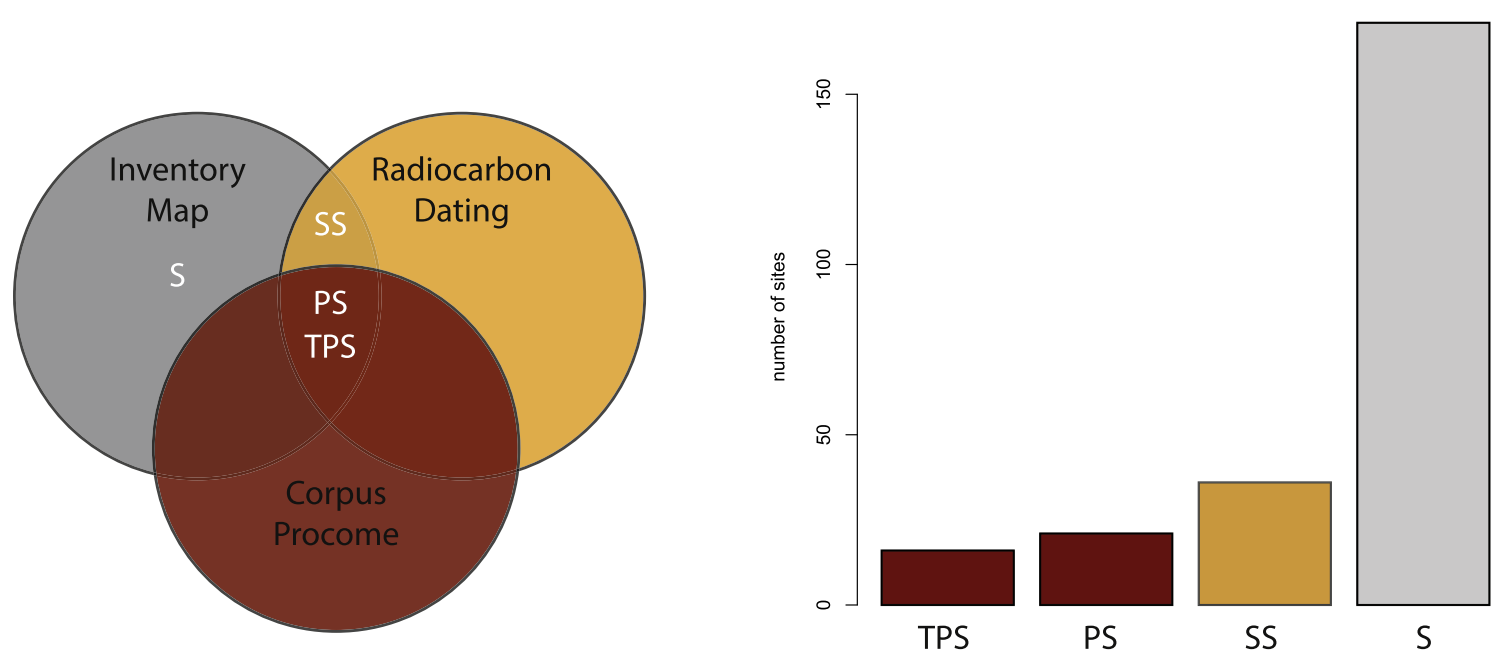

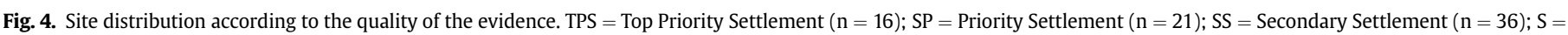

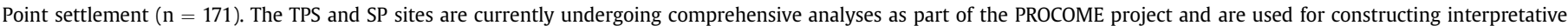
scenarios. The SS sites can be dated to clarify specific questions. The S sites are simply mentioned in inventories and used for mapping purposes.

Atlantic area (Fig. 5). The gap observed in the watershed of the Garonne is obviously problematic. The question arises as to whether this gap constitutes an archaeological reality? The significant number of rescue archaeology operations, for example in the Garonne Valley, should have compensated for this deficit. But in this area, it is likely that sedimentary dynamics contributed to making open-air settlements inaccessible, by concealing them beneath several meters, or even several dozens of meters of sediments, or that they were destroyed by major incision phases (Carozza et al., 2013). Consequently, the available data are partially biased and the watershed of the Garonne is currently beyond our reach for the construction of scenarios and will remain that way for a long time to come.

In addition to these significant geographic biases, the quality of information is very variable from one site to another. We saw above that a number of the sites correspond to early excavations or to sites where the available information is insufficient for evaluating the consistency of the units identified by various parties. Moreover, the contribution of recent excavations is unevenly spread over this geographic zone. No major Second Mesolithic or Early Neolithic sites have been excavated in the Aquitaine region over the past decades. Several sites have been surveyed or excavated, but occupations from these periods are either too fleeting or mixed with other earlier or more recent levels: this is the case for example for the sites of Gaillèbes 2 at Sabres, Lède-du-Gurp (Grayan-etl'Hôpital), Bétey (Andernos-les-Bains; unpublished), Apons Cave (Sarrance; Dumontier et al., 2016) or Bourrouilla Cave (Arancou; Dachary et al., 2013) ... In Occitania (ex- Midi-Pyrenees region), several small sites have also been published over the past 20 years, such as Buholoup rock shelter (Montberaud; Briois and Vaquer, 2009), Sanglier Cave (Reilhac; Séronie-Vivien, 2001), the Rajal del Gorp sinkhole (Millau; Bobœuf, 1998) or Clos de Poujol (Campagnac, Bobœuf et al., 2003), but again, the sedimentary and stratigraphic contexts only provide limited information. More extensive excavations at better conserved sites only began very recently, with first of all Cuzoul (Gramat) led by N. Valdeyron since 2005, then Roquemissou (Montrozier) by T. Perrin since 2012.

These two sites had already been partially excavated, and their renewed excavation enabled us to contextualize early data more accurately and to provide new information concerning these questions.

\subsection{Recent excavations}

\section{i. Cuzoul (Gramat, Lot)}

The archaeological site of Cuzoul is situated in the heart of Gramat Causse, in the north of the Lot department. It is spread out over the bottom of a vast asymmetric sinkhole hollow at an altitude of $330 \mathrm{~m}$. The site itself (Fig. 6) comprises the rear part of the entrance chamber of a relatively small cavity and its immediate surroundings, and opens in a Jurassic limestone bar forming a rocky escarpment about $10 \mathrm{~m}$ high. On either side of the cavity entrance, the rock wall extends over several tens of metres, forming a continuous line of rock shelters of variable depth.

The western flank is bordered by a wall forming a high $2-3-\mathrm{m}$ wide passage, between the wall and the bottom of the sinkhole. This corridor, which extends beyond the cliff, corresponds to a former path leading to the top of the plateau. The wide cave entrance (nearly $6 \mathrm{~m}$ ) is currently relatively low (maximum height of $2 \mathrm{~m}$ at the arrow), and leads to a first relatively vast chamber $(40 \times 15 \times 3 \mathrm{~m})$, with a constructed well at the bottom, protecting a perennial captive aquifer with annual variations of -0.5 and $-3 \mathrm{~m}$ in relation to the current floor. Beyond the well, a narrow but passable corridor leads onto a last, much smaller chamber $(8 \times 3 \times 2 \mathrm{~m})$, after about $30 \mathrm{~m}$. Only the first chamber, which is regularly flooded in the rear two-thirds during the winter due to the rise in the water table, contained archaeological remains recording occupations during prehistoric periods.

The first work on the site was conducted by R. Lacam and A. Niederlander, who worked there continuously between 1923 and 1933 (Lacam et al., 1944). First of all, three test pits were excavated inside the cavity. They only yielded levels almost totally disturbed by changes in the water table. This prompted the excavators to begin work outside the cave, in the northern shelter, from 1927 onwards. This judicious decision led to the immediate discovery of a sequence nearly $4 \mathrm{~m}$ thick with, in particular, several Mesolithic levels attributed to the Tardenoisian, on account of the presence of trapezes. The site became famous after the discovery of the grave of a young adult at the base of these "Tardenoisian" levels, and the official exploration of the site was prolonged until 1933, when the entrance test pit was filled in. More limited work was continued by R. Lacam until 1947, in a sector located about $10 \mathrm{~m}$ in front of the shelter, suggesting that layers in primary position could extend 


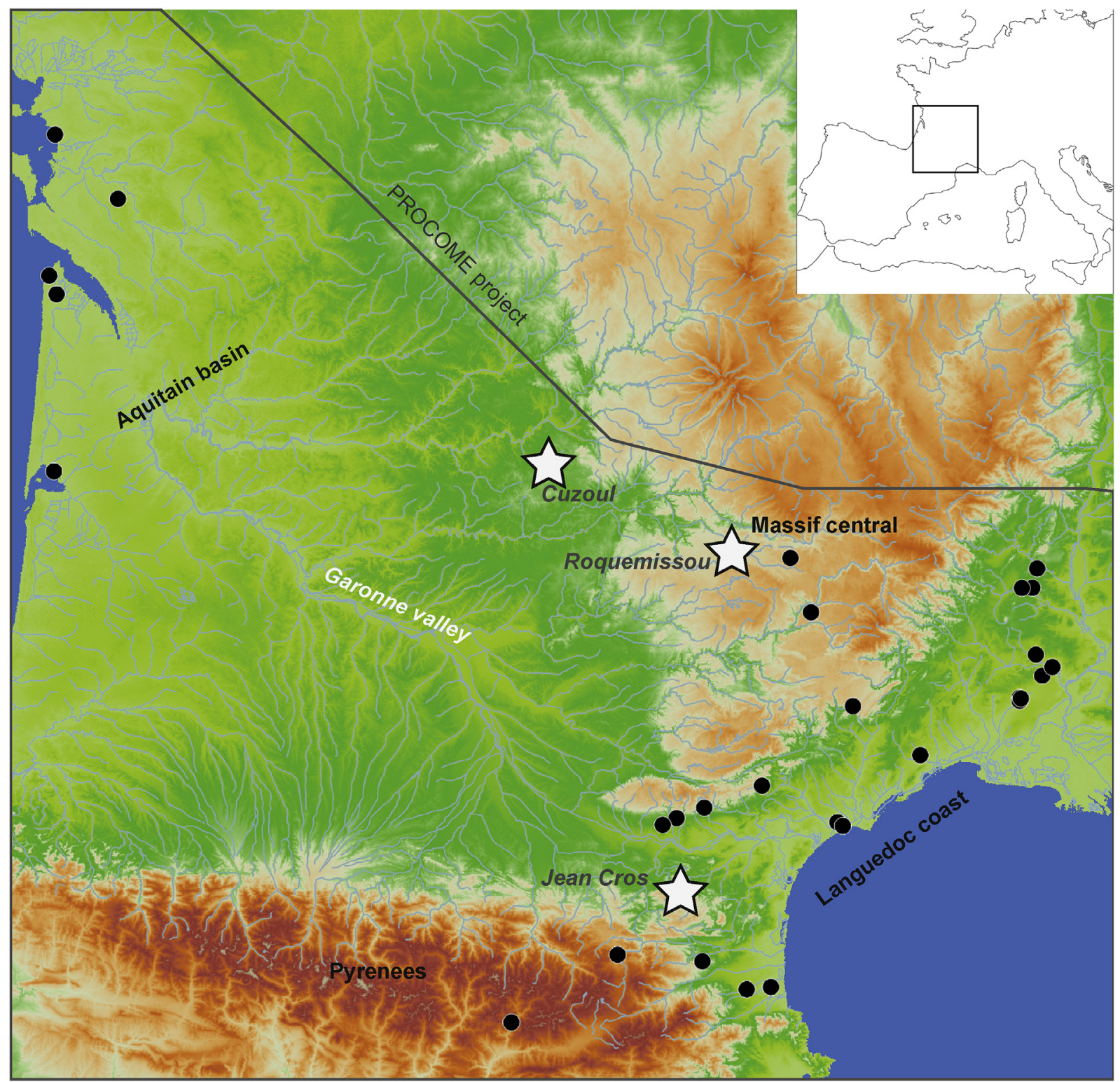

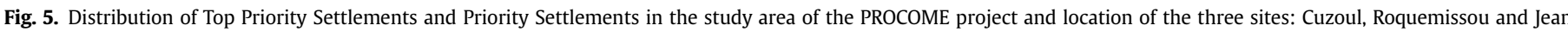
Cros.

further beyond the front of the rock shelter.

On account of these first works, the site of Cuzoul de Gramat played an important role in the construction of the chronocultural sequence of the French Mesolithic, in the same way as the eponymous sites of Sauveterre-la-Lémance (Le Martinet and le Roc Allan), excavated by L. Coulonges at practically the same time (Coulonges, 1935). Since then, these renowned sequences have been repeatedly cited in establishing explanatory models for the end of the Mesolithic. However, these convergent or opposed models (Valdeyron, 2000) are based on unreliable complexes on account of the absence of systematic sieving, which is unacceptable for this type of context.

From 2005 onwards, new archaeological excavations were carried out, under the direction of Nicolas Valdeyron, in order to obtain reliable new contextualized information on this key site. Indeed, the historiographic importance of the site and its strategic geographical position are vital for understanding Early Neolithic diffusion scenarios towards the west. After reopening former excavation sectors and sieving the rich spoil from them, new sectors were opened. These sectors were initially spatially limited and rather remote from each other, but after continual expansion, the considerable current excavated surface is more or less continuous. The whole stratigraphic sequence has thus been reassessed, and chronologically evaluated by new dates.

From a stratigraphic viewpoint, the most interesting and the most reliable sector for the questions concerning us here is the cave. There, below levels attributed to the Late Bronze Age, SU 5100 and 5110 yielded eight trapezoid armatures (type BG3; cf. Binder, 1987; Perrin, 2001), including four "Montclus arrowhead" type microliths (or BG32; ibid.). As the excavations are still ongoing, these two layers have been yet observed in only small areas (about $3 \mathrm{~m}^{2}$ ). Nevertheless, there are actually no evidences of taphonomical perturbations which could favour the hypothesis of a mixed stratigraphy (which, of course, must be confirmed).

These are geometric microliths with inverse bitruncation and direct flat retouch. They are generally made in two successive 


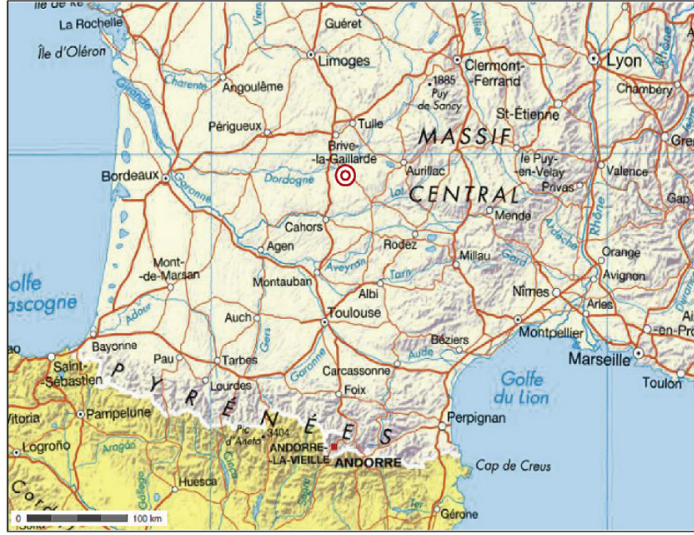

Le Cuzoul de Gramat: location map

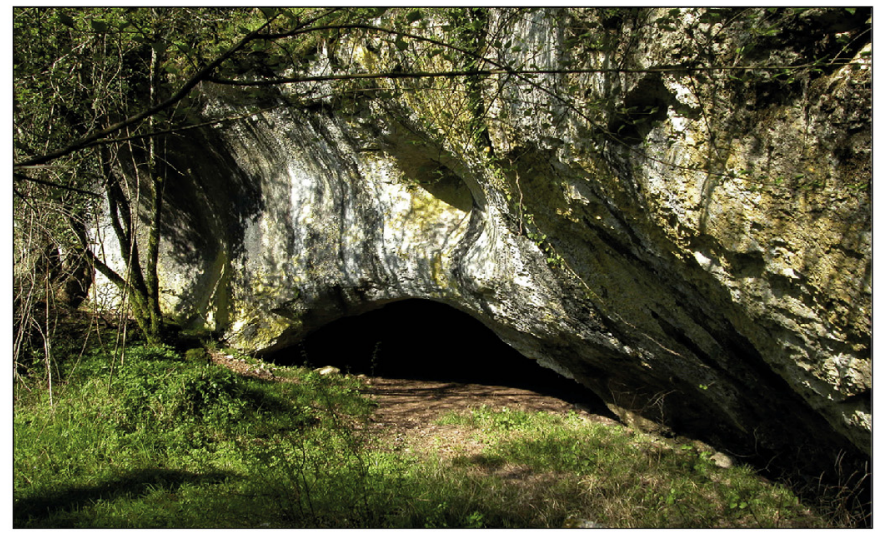

General view of the site at the begining of excavations in 2005

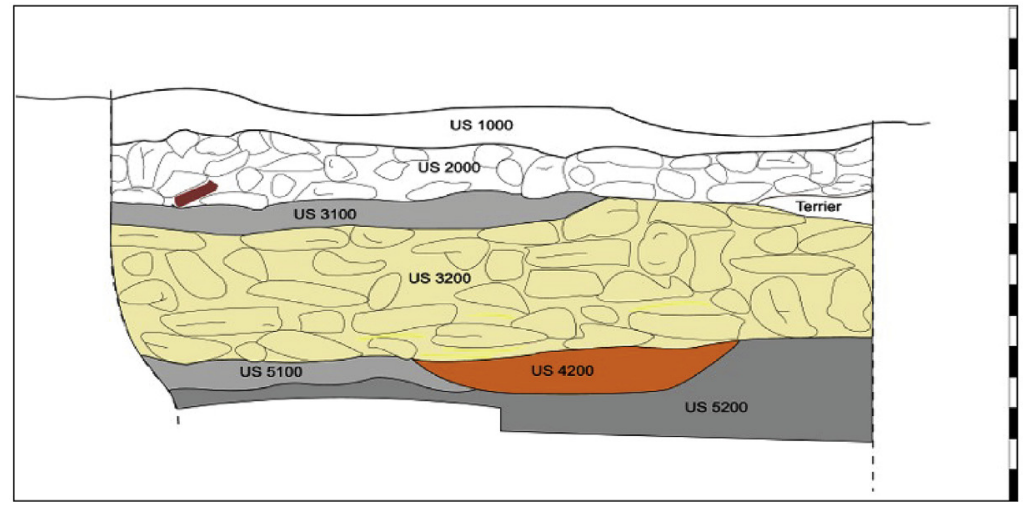

Drawing of the main stratigraphical section of the «Sondage $1 »$; the Mesolithic or Neolithic levels are the SU 5100 and 5200.
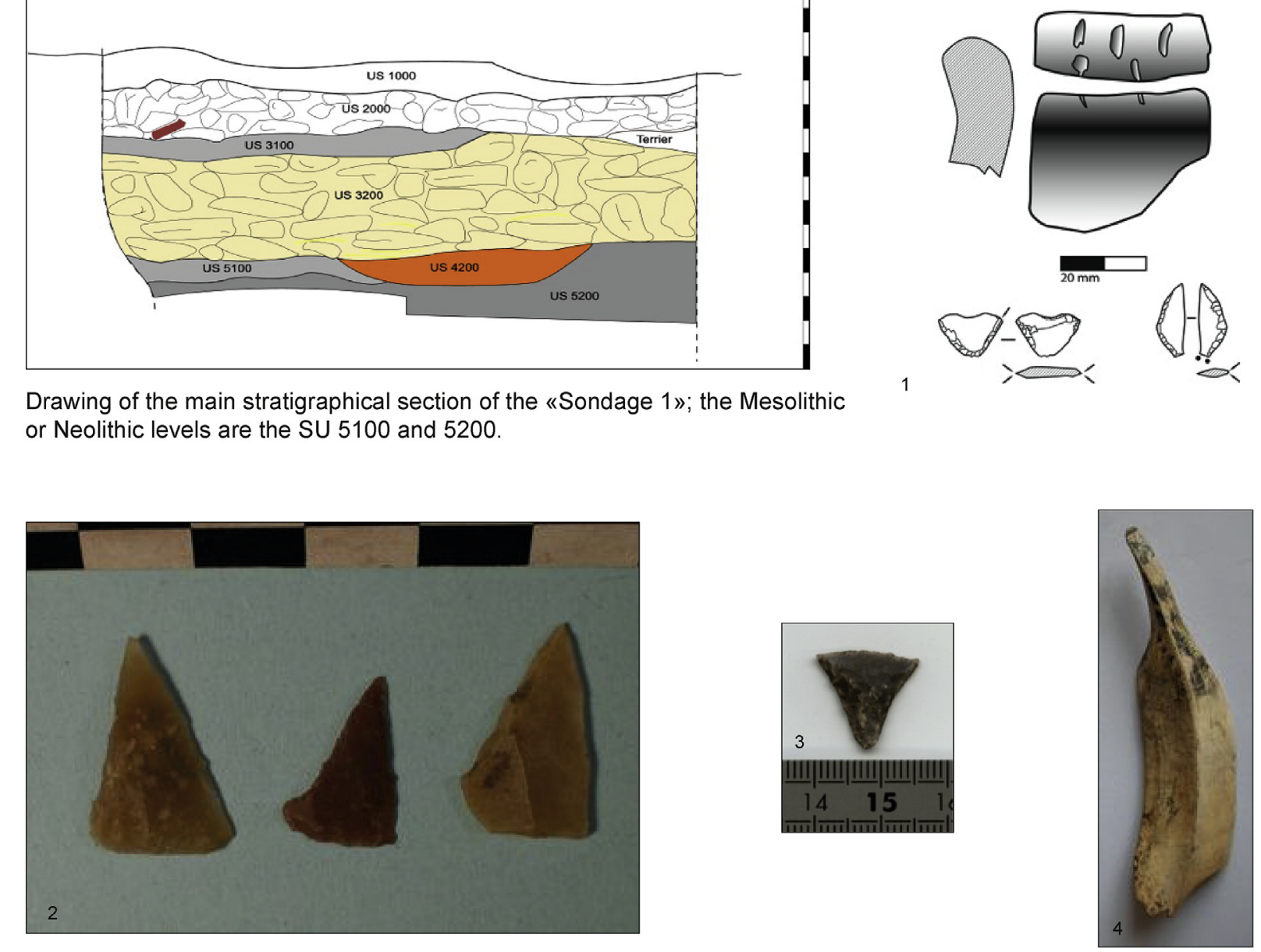

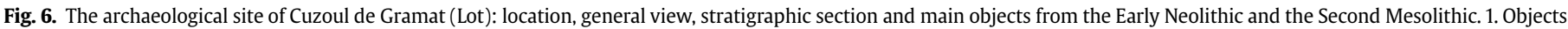

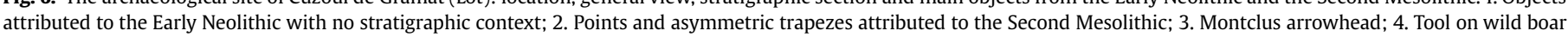
canine.

stages with two distinct intentions. In the first stage, the wide and regular laminar blank, generally with three facets, is sectioned by flexion. The break facets are then regularized by abrupt or semiabrupt inverse retouch. This first truncation phase creates an oblique surface which is then used as a retouch platform for the second phase. This second phase is geared towards thinning the initial blank by flat pressure retouch, in order to obtain an armature of regulated thickness. This technological definition includes a number of variants, particularly in terms of the extent of the flat retouch, the width of the small base, etc. This definition highlights the conceptual proximity between this BG32 type and others which only present one inverse truncation instead of two (BG34 for 
example). Variants of these two types also exist, with no flat retouch, and with inverse (type BG31) or alternate bitruncations (type BG33). The analysis of the production process shows that these diverse types are part of the same intentionality and that the hafting methods of these objects are probably similar. It is also symptomatic to note that these "Montclus arrowhead" variants are nearly always mixed together in the same occupation levels.

Regardless of this technological variability, this type of armature was identified in the 1930 s by Laurent Coulonges in his description of the levels attributed to the Tardenoisian II of the Martinet site (Sauveterre-la-Lémance, Lot-et-Garonne; Coulonges, 1935). Several years later, Raymond Lacam also pointed out the presence of "small tranchets" in the Tardenoisian II levels of Cuzoul, and more abundant objects of this type in the Tardenoisian III (Lacam et al., 1944). This particular tool type was not precisely identified until the excavations of Max Escalon de Fonton at Baume de Montclus (Gard) between 1956 and 1971. At this latter site, at the top of a sequence with occupations from the First and Second Mesolithic, three levels attributed to the Early Neolithic (layers 3, 4 and 5 Escalon de Fonton, 1971) yielded nearly 200 armatures, including about fifty Montclus arrowhead types stricto sensu. Subsequently, the development of research widened the distribution sector of these armatures to the whole of the South of France, from the Mediterranean coastline to the Atlantic shores. The origin of this "Montclus arrowhead" is obviously a crucial question. For a long time, it was presumed to derive from Mesolithic models (cf. for

Table 1

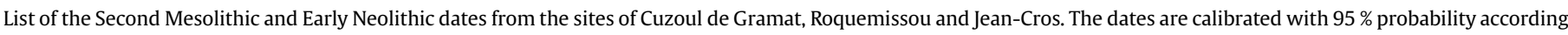
to the IntCal13 curve (Reimer et al., 2013) and the Calib v.4.2 software.

\begin{tabular}{|c|c|c|c|c|c|c|c|c|c|c|}
\hline Site & Layer & Period & Sample & Reference & $\mathrm{BP}$ & Sd & a13 & Cal $2 \sigma$ & Reliability & Reference \\
\hline $\begin{array}{r}\text { Cuzoul de } \\
\text { Gramat }\end{array}$ & CUZ06 LACAM CP A FY 1 & $\begin{array}{l}\text { Second } \\
\text { Mesolithic }\end{array}$ & charcoal & LY-14204 & 6200 & 45 & $?$ & $\begin{array}{l}-5298 / \\
-5039\end{array}$ & reliable & $\begin{array}{l}\text { Valdeyron et al. } \\
\text { (2011), p. } 208\end{array}$ \\
\hline $\begin{array}{r}\text { Cuzoul de } \\
\text { Gramat }\end{array}$ & CUZ06 LACAM CP A 2.3 FY 3 & $\begin{array}{l}\text { Second } \\
\text { Mesolithic }\end{array}$ & charcoal & LY-14205 & 6490 & 40 & $?$ & $\begin{array}{l}-5527 / \\
-5367\end{array}$ & reliable & $\begin{array}{l}\text { Valdeyron et al. } \\
\text { (2011), p. } 208\end{array}$ \\
\hline $\begin{array}{r}\text { Cuzoul de } \\
\text { Gramat }\end{array}$ & CUZ06 SD1 US 5200 & $\begin{array}{l}\text { Second } \\
\text { Mesolithic }\end{array}$ & charcoal & LY-14458 & 6815 & 40 & $?$ & $\begin{array}{l}-5763 / \\
-5633\end{array}$ & reliable & $\begin{array}{l}\text { Valdeyron et al. } \\
\text { (2011), p. } 210\end{array}$ \\
\hline $\begin{array}{r}\text { Cuzoul de } \\
\text { Gramat }\end{array}$ & CUZ07 SDL F2B & $\begin{array}{l}\text { Second } \\
\text { Mesolithic }\end{array}$ & charcoal & LY-14459 & 6760 & 60 & $?$ & $\begin{array}{l}-5751 / \\
-5558\end{array}$ & reliable & $\begin{array}{l}\text { Valdeyron et al. } \\
\text { (2011), p. } 208\end{array}$ \\
\hline $\begin{array}{r}\text { Cuzoul de } \\
\text { Gramat }\end{array}$ & CUZ08 SG5110 R12(3) rel 5b & $\begin{array}{l}\text { Second } \\
\text { Mesolithic }\end{array}$ & charcoal & LY-14921 & 6780 & 45 & $?$ & $\begin{array}{l}-5736 / \\
-5623\end{array}$ & reliable & \\
\hline $\begin{array}{r}\text { Cuzoul de } \\
\text { Gramat }\end{array}$ & CUZ09 SP 2820 & $\begin{array}{l}\text { Second } \\
\text { Mesolithic }\end{array}$ & charcoal & Lyon-6705 & 6275 & 40 & $?$ & $\begin{array}{l}-5340 / \\
-5209\end{array}$ & reliable & \\
\hline $\begin{array}{r}\text { Cuzoul de } \\
\text { Gramat }\end{array}$ & CUZ08 SG5100 SUP U10 & $\begin{array}{l}\text { Second } \\
\text { Mesolithic }\end{array}$ & charcoal & Lyon-6706 & 7060 & 45 & $?$ & $\begin{array}{l}-6018 / \\
-5844\end{array}$ & reliable & \\
\hline $\begin{array}{r}\text { Cuzoul de } \\
\text { Gramat }\end{array}$ & CUZ07 SDL CPA HA2.3 F2C & $\begin{array}{l}\text { Second } \\
\text { Mesolithic }\end{array}$ & charcoal & Lyon-5856 & 6980 & 40 & $?$ & $\begin{array}{l}-5981 / \\
-5753\end{array}$ & reliable & \\
\hline $\begin{array}{r}\text { Cuzoul de } \\
\text { Gramat }\end{array}$ & CUZ15_SG5311_2142_R12 & $\begin{array}{l}\text { Second } \\
\text { Mesolithic }\end{array}$ & bone & Beta-428096 & 6920 & 30 & $-20,9 \%$ & $\begin{array}{l}-5877 / \\
-5731\end{array}$ & reliable & \\
\hline $\begin{array}{r}\text { Cuzoul de } \\
\text { Gramat }\end{array}$ & CUZ15_CS1900_1096_R30_D16 & $\begin{array}{l}\text { Second } \\
\text { Mesolithic }\end{array}$ & bone & Beta-428097 & 6220 & 30 & & $\begin{array}{l}-5298 / \\
-5065\end{array}$ & reliable & \\
\hline $\begin{array}{r}\text { Cuzoul de } \\
\text { Gramat }\end{array}$ & CUZ15_CS1900_1245_R32_D16 & $\begin{array}{l}\text { Second } \\
\text { Mesolithic }\end{array}$ & bone (Cervus elaphus) & Beta-428098 & 6420 & 30 & $-20,2 \%$ & $\begin{array}{l}-5472 / \\
-5331\end{array}$ & reliable & \\
\hline Jean-Cros & c. 2 carrés VIII-IX-4 & $\begin{array}{l}\text { Early } \\
\text { Neolithic }\end{array}$ & charcoal & Gif-218 & 6540 & 300 & $?$ & $\begin{array}{l}-6047 / \\
-4806\end{array}$ & dubious & $\begin{array}{l}\text { Guilaine (1979), p. } \\
205\end{array}$ \\
\hline Jean-Cros & c.2b-c, carrés IX-6 et X-6 & $\begin{array}{l}\text { Early } \\
\text { Neolithic }\end{array}$ & charcoal & Gif-3575 & 6600 & 130 & $?$ & $\begin{array}{l}-5742 / \\
-5311\end{array}$ & dubious & $\begin{array}{l}\text { Guilaine (1979), p. } \\
205\end{array}$ \\
\hline Jean-Cros & c. $2 \mathrm{a}-\mathrm{b}$ & $\begin{array}{l}\text { Early } \\
\text { Neolithic }\end{array}$ & charcoal & MC-785 & 4600 & 100 & $?$ & $\begin{array}{l}-3634 / \\
-3026\end{array}$ & dubious & $\begin{array}{l}\text { Guilaine (1979), p. } \\
207\end{array}$ \\
\hline Jean-Cros & c. $2 \mathrm{c}$ & $\begin{array}{l}\text { Early } \\
\text { Neolithic }\end{array}$ & charcoal & MC-786 & 4450 & 100 & $?$ & $\begin{array}{l}-3484 / \\
-2896\end{array}$ & dubious & $\begin{array}{l}\text { Guilaine (1979), p. } \\
207\end{array}$ \\
\hline Jean-Cros & c.2a-b & $\begin{array}{l}\text { Early } \\
\text { Neolithic }\end{array}$ & sooty earth & MC-935 & 4530 & 100 & $?$ & $\begin{array}{l}-3516 / \\
-2925\end{array}$ & dubious & $\begin{array}{l}\text { Guilaine (1979), p. } \\
207\end{array}$ \\
\hline Jean-Cros & c.2a-b-c, carrés VI-6 & $\begin{array}{l}\text { Early } \\
\text { Neolithic }\end{array}$ & shell (Helix) & Gif-3576 & 7160 & 130 & $?$ & $\begin{array}{l}-6347 \mid \\
-5747\end{array}$ & dubious & $\begin{array}{l}\text { Guilaine (1979), p. } \\
205\end{array}$ \\
\hline Jean-Cros & JC-VI4-2b-92 & $\begin{array}{l}\text { Early } \\
\text { Neolithic }\end{array}$ & bone (Caprinae) & Beta-398981 & 6070 & 30 & $-21,7 \%$ & $\begin{array}{l}-5189 / \\
-4851\end{array}$ & reliable & \\
\hline Jean-Cros & JC-V2-2a & $\begin{array}{l}\text { Early } \\
\text { Neolithic }\end{array}$ & bone (Caprinae) & Beta-398982 & 1750 & 30 & $-19,7 \%$ & $222 / 385$ & dubious & \\
\hline Jean-Cros & JC-XI6-2a-40 & $\begin{array}{l}\text { Early } \\
\text { Neolithic }\end{array}$ & bone (Cervus elaphus) & Beta-398983 & 5910 & 30 & $-21,0 \%$ & $\begin{array}{l}-4844 / \\
-4715\end{array}$ & reliable & \\
\hline Roquemissou & US 5311 & $\begin{array}{l}\text { Early } \\
\text { Neolithic }\end{array}$ & bone (Sus scrofa scrofa) & Beta-460504 & 5870 & 30 & $-20,2 \%$ & $\begin{array}{l}-4795 /- \\
4690\end{array}$ & reliable & \\
\hline Roquemissou L & US 1101, FY1101 & $\begin{array}{l}\text { Second } \\
\text { Mesolithic }\end{array}$ & bone (Sus sp.) & Beta-363428 & 6630 & 40 & $-19,3 \%$ & $\begin{array}{l}-5626 / \\
-5491\end{array}$ & possible & \\
\hline Roquemissou L & US 1040 & $\begin{array}{l}\text { Second } \\
\text { Mesolithic }\end{array}$ & $\begin{array}{l}\text { plant macrofossil } \\
\text { (Corylus avellana) }\end{array}$ & $\begin{array}{l}\text { Lyon-11260 } \\
\text { (SacA-37626) }\end{array}$ & 7150 & 35 & $?$ & $\begin{array}{l}-6075 / \\
-5930\end{array}$ & reliable & \\
\hline Roquemissou L & US 1081 & $\begin{array}{l}\text { Second } \\
\text { Mesolithic }\end{array}$ & bone (Bos sp.) & Beta-363427 & 7500 & 40 & $-21,3 \%$ & $\begin{array}{l}-6442 / \\
-6253\end{array}$ & reliable & \\
\hline Roquemissou L & US 5435 & $\begin{array}{l}\text { Second } \\
\text { Mesolithic }\end{array}$ & bone (Capreolus sp.) & Beta-398965 & 7140 & 30 & $-22,3 \%$ & $\begin{array}{l}-6066 / \\
-5931\end{array}$ & reliable & \\
\hline Roquemissou L & US 1184 & $\begin{array}{l}\text { Second } \\
\text { Mesolithic }\end{array}$ & bone (indet.) & $\begin{array}{l}\text { Lyon-12839 } \\
\text { (SacA-45094) }\end{array}$ & 7545 & 40 & $?$ & $\begin{array}{l}-6470 / \\
-6267\end{array}$ & reliable & \\
\hline Roquemissou & US 1120 & $\begin{array}{l}\text { Second } \\
\text { Mesolithic }\end{array}$ & bone (indet.) & $\begin{array}{l}\text { Lyon-12841 } \\
\text { (SacA-45096) }\end{array}$ & 7000 & 45 & $?$ & $\begin{array}{l}-5988 / \\
-5770\end{array}$ & reliable & \\
\hline
\end{tabular}


example Escalon de Fonton, 1966; 1968, Rozoy, 1971, 1978 or Barbaza, 1993). Contrary to these hypotheses stressing the continuity and local evolutions of these types of armatures, Didier Binder highlights the "total" rupture (technological, typological and functional; Binder, 1987, p. 172) between Castelnovian trapezes and cutting Neolithic armatures. For the latter author, geometric microliths with inverse truncations are specifically Early Neolithic tools. This position considering Montclus arrowheads, and by extension the diverse class BG3 trapezes, as characteristic of the Early Neolithic in the South of France, has been adopted by most researchers over the past years.

Yet data from the new Cuzoul excavations call into question the relevance of this paradigm. Indeed, in SU 5100 and 5110, these geometric bitruncations are associated with other typical Aquitaine Mesolithic armatures: Martinet's trapezes and various triangular points (Fig. 6). From a technological perspective, it is possible to compare the mixed Aquitaine points with the "Montclus arrowheads", as similar intentions guided the shaping of the base of these points. The Martinet trapezes are defined as direct asymmetric bitruncations with inverse retouch at the base, whereas the mixed points correspond to triangular alternate bitruncations where the small truncation generally bears direct flat secondary retouch. For the time being, no indication of pottery, cereals or domestic animals have been found in these two stratigraphic units. Moreover, micro- charcoal from SU 5110 has been dated between 5700 and 5600 cal. BC (Ly-14921: $6780 \pm 45$ BP or $5740-5620$ cal. BC with $95 \%$ probability - Table 1 and Fig. 7). If this single date is confirmed by new ones, it excludes a possible attribution to the Early Neolithic (cf. Fig. 2). More generally, the presence of these armatures in this level suggests that they are a Mesolithic invention, which profoundly upsets our perception of contact and exchange scenarios between Mesolithic and Neolithic groups. We will develop this point below.

\section{ii. Roquemissou (Montrozier, Aveyron)}

The archaeological site of Roquemissou is located $15 \mathrm{~km}$ east of Rodez, on the townland of Montrozier (Aveyron), at the foot of a long rocky bar of Bajocian oolithic limestone bordering the alluvial plain of the Aveyron, on the right bank (Fig. 8). This 15-20-m high rocky bar presents a relatively marked profile and is clearly visible in the landscape. In places, such as above the sheep pen, this overhang still measures three to $4 \mathrm{~m}$, but in other sectors, it has totally disappeared after partial collapse. This collapsing could have been relatively massive, as shown by several multi-metric blocks scattered in front of the rocky bar, towards the Aveyron.

After the discovery of the site in 1978, ten excavation seasons took place between 1982 and 1991, directed by Gaston-Bernard Arnal (CNRS). The initial fieldwork was disrupted by illicit

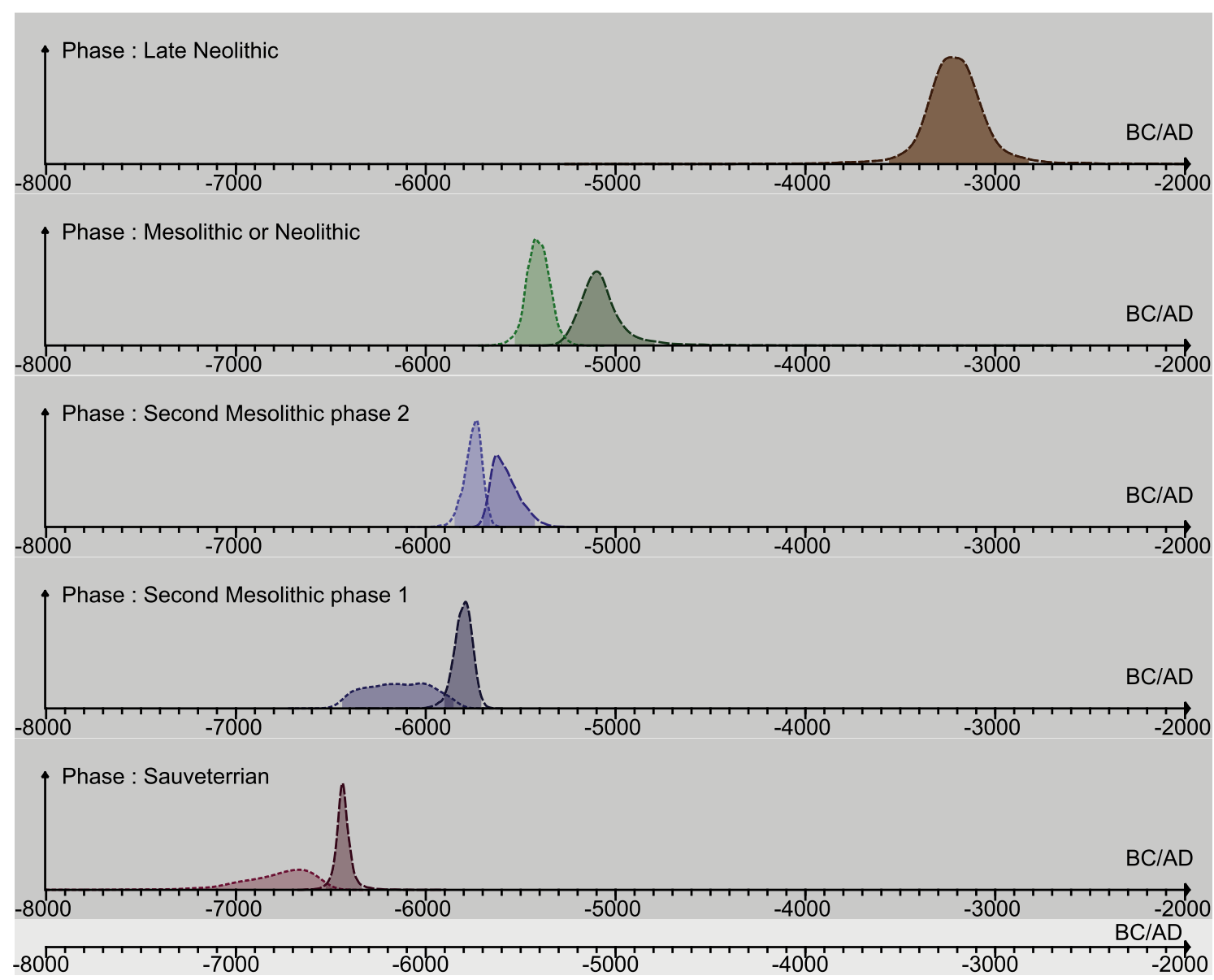

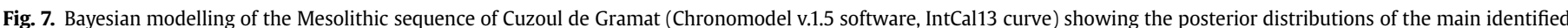

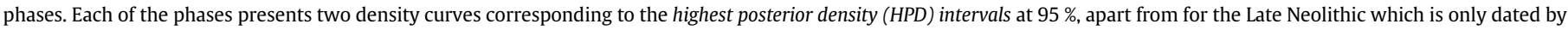

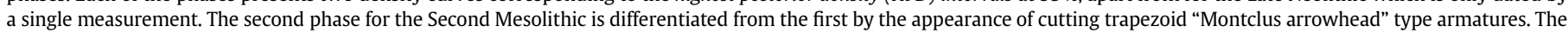

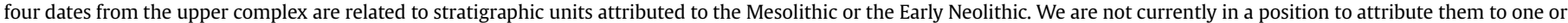

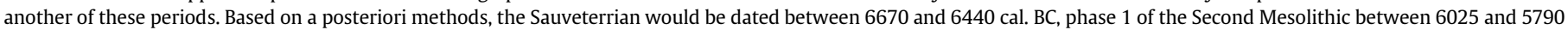
cal. BC and phase 2 between 5730 and 5630 cal. BC. The indeterminate levels between the Mesolithic and the Neolithic are situated between 5420 and 5100 cal. BC. 


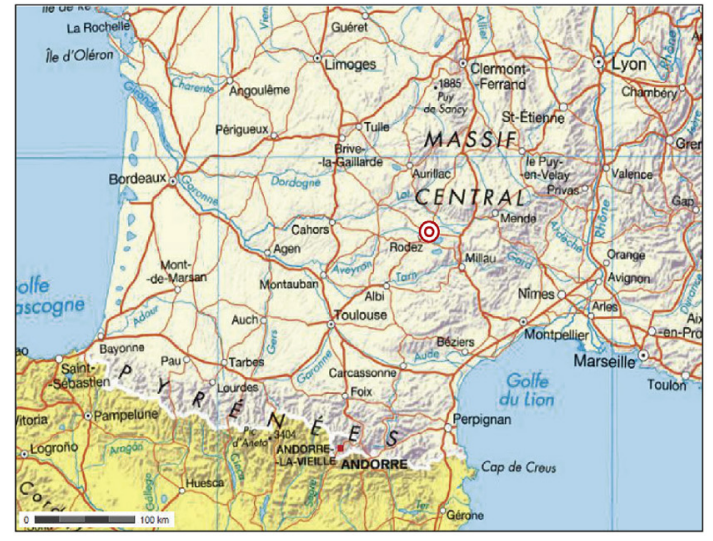

Roquemissou: location map

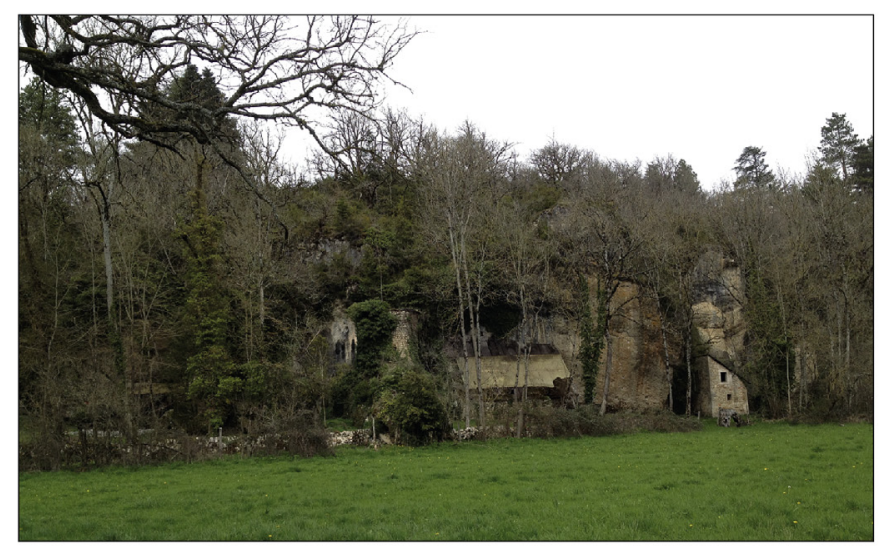

General view of the site, at the cliffs foot

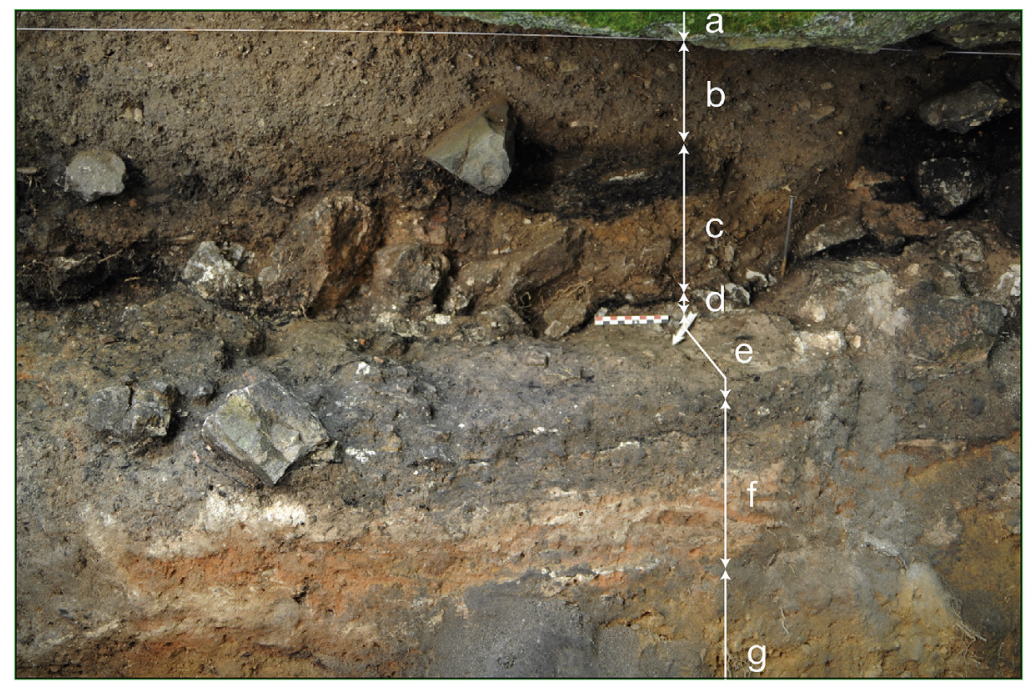

a. Collapse block.

b. Sterile colluvium.

c. Several layers and hearths of the Late Neolithic / Bell Beaker era (between 2900 and 2300 cal. BC).

d. Early Neolithic layer (arround 4800-4700 cal. BC).

e. Recent Mesolithic, several occupations between 6000 and 5500 cal. BC.

f. Numerous hearths and layers of the First Mesolithic era, between 7500 and 6700 cal. BC

g. Yellow sandy levels including numerous hearths dated of the Late Azilian, around $11300-11100 \mathrm{cal}$. BC.

Partial view of the stratigraphical section S.08

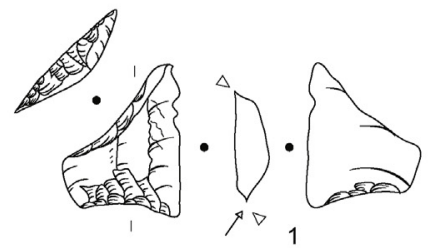

Arrowhead's scale (1:1)

Sherds' scale $(2: 3)$
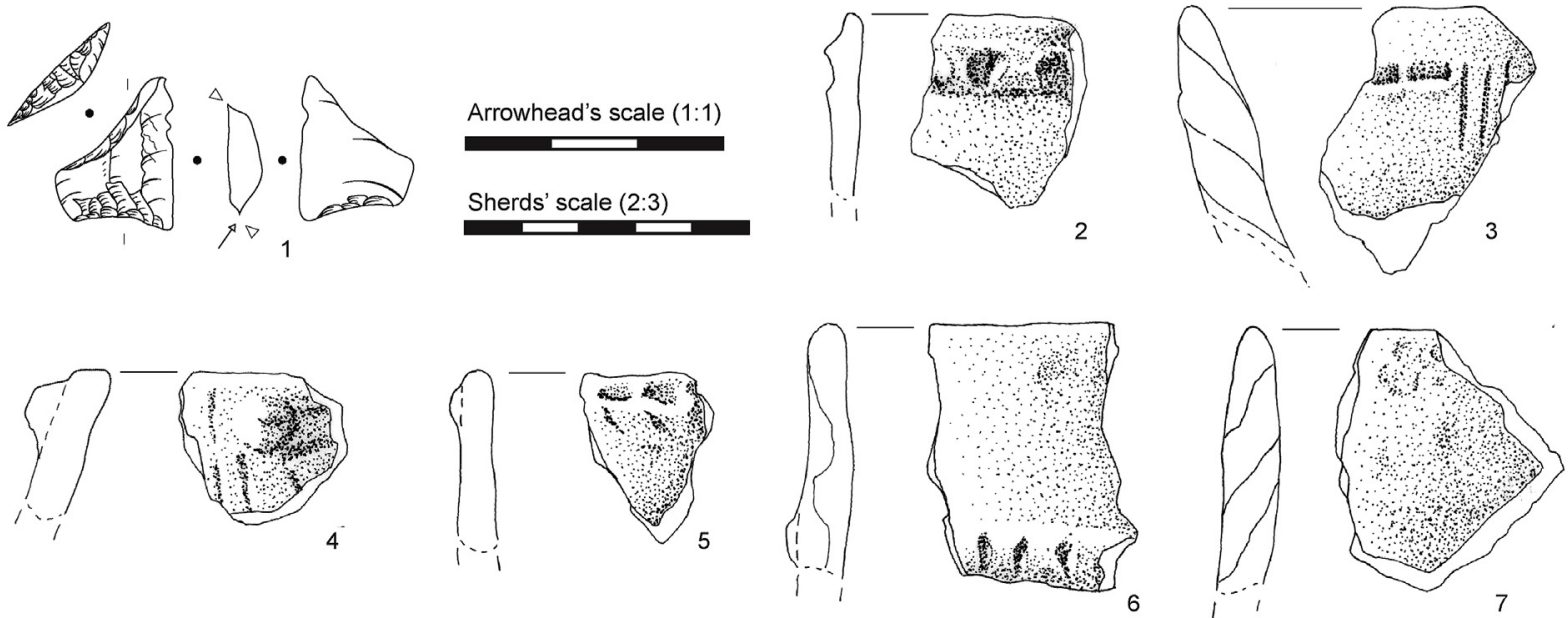

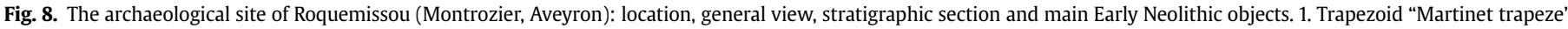

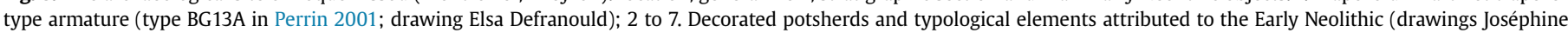
Caro).

excavations, but nonetheless identified a stratigraphic sequence extending from the end of the Upper Paleolithic to the Early Neolithic. However, the convergence of the illicit excavation, in the centre of the opened surface, with a complex and relatively dense stratigraphy, led to the identification of a transition unit between the Mesolithic and the Early Neolithic. This explains why G.-B. Arnal tended to attribute almost all of the stratigraphic complex from locus I to the Early Neolithic "Roucadourian" (Arnal, 1983; 1995, 2006). Today, the consensus is that this term must be abandoned as it always includes mixed series, rather than coherent 
complexes (Marchand, 1999). At Roquemissou, this "Early Neolithic" was characterized by the association of relatively coarse pottery with a lithic industry with mixed characters deriving from the Second Mesolithic (Martinet trapezes for example) and from the Early Neolithic (Montclus arrowheads for example: Arnal, 1995). There, like elsewhere in the ex-Roucadourian, the question of the homogeneity of the assemblage was raised, and was particularly acute due to the limited stratigraphic thickness. The presence of objects characteristic of the Second Mesolithic strongly suggested the existence of an occupation during this period mixed with Neolithic remains, artificially creating a "mixed unit". A new series of excavations was thus resumed in 2012.

Several surveys and manual test pits enabled us to enhance our understanding of the sedimentary and taphonomic dynamics at work at the site. The prehistoric occupations appear to have extended towards the Aveyron, to the south, but multiple erosion dynamics have practically totally destroyed them. The archaeological layers were only conserved just below the cliff itself, over a width of about 4 or $5 \mathrm{~m}$. The rectification of the limits of the former excavation led to the formation of two large stratigraphic reference profiles, which perfectly illustrate the complexity of the very anthropized and only slightly sedimented infilling. A first geoarchaeological analysis imputes this absence of sedimentation to the specific layout of the occupations, between heaps of collapsed blocks from the cliff overhang, forming natural barriers to potential colluvium deposits. Furthermore, the analysis of these deposits is complex as most of them present a "hollow" profile. Numerous combustion structures are superposed in this part of the site, and are related to the Epipaleolithic, the First and Second Mesolithic, the Early Neolithic and the Late Neolithic. The archaeological sequence currently documented at Roquemissou thus covers more than nine millennia from $11,300 \mathrm{cal}$. BC to $2300 \mathrm{cal}$. BC.

The Second Mesolithic occupations, combining wide blades and asymmetric trapezes, have only been partially explored by the new excavations. However, they contain characteristic objects, attributed to the second half of the seventh millennium and the first half of the sixth millennium on the basis of several radiocarbon dates (Table 1). The Early Neolithic levels (corresponding to the first occurrences of pottery at the site) are well recorded, particularly from a planimetric viewpoint, with stone combustion structures spread out over the whole excavated surface (about fifty square metres). They have been recently dated to the first quarter of the fifth millennium cal. BC (Beta-460504 - Table 1), which is consistent with the dates of some others hinterland sites, like Jean-Cros (see hereafter). They correspond to habitat types, with rare small pottery shards, sometimes decorated with regionally known standards (Defranould et al., 2017), several lithic elements and a lot of faunal remains, which are exclusively wild, for the moment.

This level directly overlies the stratigraphic units of the Second Mesolithic and is covered by a significant Late Neolithic occupation, which was not identified as such during the previous excavations. Our new excavations showed that this Late Neolithic occupation corresponds to the remains of a built settlement, probably a village, attributed to the Treilles and Bell Beaker culture, during the middle of the third millennium cal. BC. The combination of a very low to non-existent sedimentation rate, diverse anthropogenic occupations, discrete Early Neolithic occupations in the part of the site where previous excavations took place and the absence of identification of the Late Neolithic occupation resulted in the identification of a mixed pseudo-facies. As a matter of fact, it is only mixed because the same unit artificially mixes remains from three distinct occupation phases: the Second Mesolithic, Early Neolithic and the Late Neolithic. The renewed excavations thus show that the mixed facies previously identified at Roquemissou does not exist, which is an additional argument (if one was required) for the definitive abandonment of the Roucadourian.

As far as the material production is concerned, the Early Neolithic level of Roquemissou also enables us to question our "traditional" interpretations in a sort of mirror effect of Cuzoul. Indeed, whereas at Cuzoul we saw that the armatures considered to be characteristic of the Early Mediterranean Neolithic up until then were present in levels a priori strictly Mesolithic, Roquemissou seems to yield a type of typically Mesolithic armature in a level $a$ priori strictly Neolithic ... In fact, SU 5311 contains pottery shards, fauna and a wide trapezoid but asymmetric "Martinet trapeze" type armature under a stone hearth (Fig. $8 n^{\circ} 1$ ). Yet this type of object is generally considered to be characteristic of the Second Mesolithic of Aquitaine! For the time being, this is the only object of its kind in a stratified site and it is obviously not possible to confirm the reality of this association, even though no arguments on site suggest clear reworking in this zone.

\subsection{Revision of earlier data}

These new excavations are clearly of prime importance for renewing our knowledge but it also seemed important to us to include data acquired from former excavations, for a critical approach backed up by new analyses.

This critical examination of existing data was carried out as part of the ANR Procome programme, as we mentioned above. 35 sites of secondary quality (SS) were identified and, in spite of certain limitations, are likely to provide significant complementary information. At some of these sites, new studies of archaeological remains were carried out, as well as radiocarbon dates to position the different occupations in the most accurate possible timeframe. The Jean-Cros rock shelter is a good illustration of this approach.

The Jean-Cros rock shelter is situated in the western reaches of the Corbières, in the Aude, on the townland of Labastide-en-Val. Jean Guilaine surveyed the site in 1963 and 1964, then excavated there between 1966 and 1968 (Guilaine, 1979). The stratigraphy of the rock shelter yielded a sequence of occupations from the end of the Iron Age, The Bronze Age and the Early Neolithic. Layer 2, divided into three theoretical levels (c.2a, c.2b and c.2c), contained a small Early Neolithic assemblage with several pottery vessels, a lithic industry primarily composed of arrowheads, but also polished axes, a bone industry and several ornamental elements, in particular marine shells. In the 1970s, this discordant assemblage of objects in relation to strictly Cardial coastal assemblages was used to define the Pericardial as a "diminished lateral facies corresponding to the adoption of the pottery technique by inland populations using influences from coastal zones" (Guilaine, 1986) due to the "poor quality" of the pottery and the abundance of arrowheads. According to some authors, this site thus provided evidence of a mixed transitional Meso-Neolithic facies. Several series of dates were carried out in the 1970s on charcoal and Helix shells. However, the samples were not conducive to dating and the dates are inconsistent. The MC-785, MC-786 and MC-935 dates seem to correspond to Late Neolithic pollution (not identified at the excavation?). In order to refine the chronology of the occupation of layer 2 , we selected three faunal samples (Table 1 ). One of these results is related to the Iron Age occupation, pointing to post-positional disturbance, whereas the two others are consistent with the Neolithic chronology. These two dates are statistically different (Chi-2 $=14.2$, df $=1, \mathrm{p}$-value $=3.84, \alpha=5 \%$ ) and respect the stratigraphic sequence. The first is between 5050 and 4900 cal. BC (Beta-398981), the second between 4850 and 4715 cal. BC (Beta398983). These dates thus place the site in a very recent Early Neolithic timeframe. They tend to reject the hypothesis of material derived from an acculturation process in favour of a functional and/ or economic interpretation, that is, a site frequented occasionally by 
groups of agro-pastors. The data obtained from the petrographic analysis of the clay raw materials used to make the pottery from layer 2 also argue in favour of this as six out of the seven analysed pottery vessels were made with exogenous clay (from several dozen kilometres away), whereas suitable marly-clayey deposits for modelling, are found locally (Manen and Guilaine, 2010). Lastly, for Jean-Cros, the term "Pericardial" could designate a functional value ("specialized" site or halt) rather than cultural connotations (issued from the acculturation of the last hunter-gatherers). The revised interpretation of the status of the site as a "shepherds' shelter, using one or several relatively unsuitable ecological niches for agriculture through livestock farming" also points to a similar analysis (Guilaine et al., 1993, p. 472).

This example illustrates that the hasty use of cultural mechanisms to define the Early Neolithic in the hinterland as a distinct cultural entity is not necessarily the most pertinent approach and that we should also look for functional or economic mechanisms (the whole technical system must then be analysed in detail without focusing on pottery production; Defranould et al., 2017). These interpretations are in keeping with the mobile and combined socio-economic organization of the environment of Cardial and Epicardial societies.

Ongoing research at these two sites of Cuzoul and Roquemissou and the reassessment of former data (like for Jean-Cros) incite us to question not only our reading and interpretation of the archaeological assemblages but also the very concepts of the Mesolithic and the Neolithic, which seem to become increasingly interchangeable moving inland from the coast.

\section{Discussion}

Today, new excavations and collective works thus enable us to reassess our knowledge and to reappraise the reliability of interpretative scenarios for the continental extension of Mediterranean neolithisation, in particular towards the Southwest of France. It is clear that simple "wave of advance" type scenarios are no longer operative and that the complexity of the mechanisms at work in the diffusion of new Neolithic techno-economic characteristics towards the hinterland must be broached using a suitable approach. And this approach must, above all, include a critical analysis of the sedimentary sequences of stratified sites. For this question of transitions, it is essential to identify sedimentary compacting or truncation. If these processes are not accurately identified, they are likely to back up unfounded scenarios of continuity between the last hunter-gatherer societies and the first farmers. In the Mediterranean zone, this has been demonstrated for the site of Sidari (Corfu, Grece, Berger et al., 2014) where the geoarchaeological analysis confidently identified stratigraphic and chronological discontinuity between the last Mesolithic levels and the first Neolithic levels. The same is true of the emblematic site of Cocina (Valencia, Spain, Juan Cabanilles and García Puchol, 2013), where recent work (new excavation and stratigraphic revision, new dating, revised study of the objects ...) showed the existence of a rupture between the Mesolithic and Neolithic levels. Let us recall that in the 1970s (Fortea Pérez, 1973), the stratigraphy of this site was interpreted as evidence of a gradual acculturation process of the last hunters by the first Cardial Neolithic groups.

In our study region, the sites used for these scenarios are mostly stratified sites (Le Martinet, La Poujade, Roquemissou, CombeGrèze ... cf. Marchand, 1999), with relatively long, and always recurrent occupations. Ongoing excavations, backed up by detailed geoarchaeological analyses, show the complexity of the sedimentary and taphonomic processes at work in these contexts. These new approaches should lead to the reconsideration of the reliability of early data, particularly in the Midi-Pyrenees. In the long run, the latter are of little use today for approaching these questions of transition and can only be used to signal the presence or absence of specific technical criteria. Consequently, this type of analysis is still rather imprecise, but stratigraphic mixing polluted analyses and hindered interpretations for too long to be able to continue the analysis of these assemblages.

Current ongoing excavations and newly acquired chronological data now enable us to outline several, relatively reliable observations. Over one hundred new AMS dates were taken from samples with a short life cycle as part of the ANR Procome research programme, which confirms that there are very scarce evidences of Mesolithic presence after 5800 Cal. BC (Perrin, 2013). Some data from Cuzoul de Gramat suggest that Mesolithic groups could have existed until 5200 Cal. BC in this particular area, but this has yet to be confirmed.

The first agro-pastoral settlements appear towards 5700 Cal. BC on the coast, and therefore Mesolithic and Neolithic groups could theoretically have been in contact. But, at the present time, no clear demonstration of direct contacts between them has been established. A chronological gap of one to several centuries always exists between them when they are present at the same site or a distance of several dozen or even several hundred kilometres when they are contemporaneous (Perrin, 2013). However, the existence of such contacts could be indirectly indicated by the distribution of a particularly type of arrowheads, the "Montclus arrowheads", which are present in both groups and which provide evidence of reciprocal assimilations for the whole Southern France, even though we cannot yet, in this case, define the exact nature of these exchanges (Perrin et al., in press).

The assemblages from these hinterland sites are difficult to interpret as they represent a mixture of specific local features, specific site functions and assemblage recomposition (Defranould et al., 2017). The same problem occurs in other regions, like in the Northern Italian Alps (Perrin, 2005) or the Ebro valley (Utrilla and Domingo, 2014; García-Martínez de Lagrán, 2017). The functional variability of sites, in particular, raises problems: how can we interpret a site that only contains wild fauna, rare or no pottery remains and an industry that cannot be attributed to one or the other of the groups? A Neolithic hunting camp or Mesolithic base (Binder, 1991)? In fact, the Mesolithic/Neolithic distinction seems at times too simplistic to realistically take account of the facts and too dichotomist to reliably characterize any intermediate transition, or acculturation facies. New paradigms will need to be created, in order to take into consideration the far-flung diversity of the developments at work in the continental extension of Mediterranean neolithisation.

\section{Acknowledgements}

This work was supported by the French National Research Agency "ANR-13-CULT-0001-01" www.anrprocome.com, the French Ministry of Culture and Communication, Program 10 "Le Mésolithique" and 11 "Apparition du Néolithique et du Néolithique ancien" of the French national council for archaeological research, the Conseil départemental de l'Aveyron, the Conseil général du Lot and the association Archéologies.

\section{References}

Ambert, P., André, J. Leroy, S.A.G., 1995. L'évolution holocène de la lagune de Narbonne (sud de la France). Premiers enseignements d'une recherche pluridisciplinaire initiée par Jean Guilaine. Cultures i Medi de la prehistória a l'edat mitjana. 20 anys d'arqueologia pirinenca. Homenatje al Professor Jean Guilaine. Institut d'Estudis ceretans, Puigcerdà, pp. 63-70.

Ammerman, A.J., Cavalli-Sforza, L.L., 1984. The Neolithic Transition and the Genetics of Populations in Europe. Princeton University Press, Princeton. 
Arnal, G.-B., 1983. Abri sous roche de Roquemissou (Montrozier). Travaux. Club d'Archéologie - Maison des Jeunes et de la Culture, pp. 65-68.

Arnal, G.-B., 1995. Le Néolithique roucadourien. In: Voruz, J.-L. (Ed.), Chronologies néolithiques. De 6000 à 2000 avant notre ère dans le bassin rhodanien. Sociét préhistorique rhodanienne, Ambérieu-en-Bugey, pp. 67-74.

Arnal, G.-B., 2006. Le Néolithique ancien des Grands Causses. In: Gascó, J., Leyge, F. Gruat, P. (Eds.), Hommes et passé des Causses : hommage à Georges Costantini : actes du Colloque de Millau, 16-18 juin 2005. Archives d'Ecologie préhistorique/ Musée de Millau, Toulouse/Millau, pp. 71-84.

Barbaza, M., 1993. Technologie et culture du Mésolithique moyen au Néolithique ancien dans les Pyrénées de l'Est. In: Guilaine, J., Barbaza, M., Gascó, J. (Eds.) Dourgne: derniers chasseurs-collecteurs et premiers éleveurs de la HauteVallée de l'Aude. Centre d'Anthropologie des Sociétés rurales/Archéologie en Terre d'Aude, Toulouse/Carcassonne, pp. 425-441.

Berger, J.-F., Metallinou, G., Guilaine, J., 2014. Vers une révision de la transition méso-néolithique sur le site de Sidari (Corfou, Grèce). Nouvelles données géoarchéologiques et radiocarbone, évaluation des processus postdépositionnels. In: Manen, C., Perrin, T., Guilaine, J. (Eds.), La transition néolithique en Méditerranée. Errance/Archives d'Ecologie préhistorique, Arles Toulouse, pp. 213-232.

Bernabeu Aubán, J., Barton, C.M., Pardo Gordó, S., Bergin, S.M., 2015. Modeling initial Neolithic dispersal. The first agricultural groups in West Mediterranean. Ecol. Model. 307, 22-31.

Bernabeu Aubán, J., Barton, C.M., Perez Ripoll, M., 2001. A Taphonomic Perspective on Neolithic Beginnings: Theory, Interpretation, and Empirical Data in the Western Mediterranean. eng 28, pp. 597-612.

Bernabeu Aubán, J., Manen, C., Pardo, S., 2017. Spatial and temporal diversity during the Neolithic spread in the western Mediterranean. In: Garcia Puchol, O., Salazar García, D.C. (Eds.), Times of Neolithic Transition along the Western Mediterranean. Springer (in press).

Biagi, P., 2003. A review of the late Mesolithic in Italy and its implication for the Neolithic transition. In: Ammerman, A.J., Biagi, P. (Eds.), The Widening Harvest: the Neolithic Transition in Europe: Looking Back, Looking Forward. Archaeological Institute of America, Boston, pp. 133-156.

Binder, D., 1987. Le Néolithique ancien provençal: typologie et technologie des outillages lithiques. CNRS, Paris.

Binder, D., 1991. Une économie de chasse au Néolithique ancien : la grotte Lombard à Saint-Vallier-de-Thiey (Alpes-Maritimes). Monographie du CRA 5, CNRS, Paris.

Binder, D., 2013. Mésolithique et Néolithique ancien en Méditerranée nordoccidentale entre 7000 et 5500 cal. BCE: questions ouvertes sur les dynamiques culturelles et les procès d'interaction. In: Jaubert, J., Fourment, N. Depaepe, P. (Eds.), Transitions, ruptures et continuité en Préhistoire, Évolution des techniques - Comportements funéraires - Néolithique ancien, vol. 1. Société préhistorique française, Paris, pp. 341-355.

Binder, D., Sénépart, I., 2010. La séquence de l'Impresso-Cardial de l'abri Pendimoun et l'évolution des assemblages céramiques en Provence. Premières Soc. paysannes Méditerr. Occident. Struct. Prod. Céram. 149-167.

Bobøuf, M., 1998. Les vestiges lithiques des occupations mésolithiques et néolithiques de l'Aven du Rajal del Gorp (Millau, Aveyron). Préhistoire Du. SudOuest 5, 147-161.

Bobøuf, M., Bridault, A., Brochier, J.É,, David, E., Loiseleur, B., Marinval, P., Marquet, J.-C., 2003. Le Clos de Poujol (Aveyron), fouilles programmées triennales 2001-2002-2003. Rapport triennal 2003. Service Régional de l'Archéologie, Toulouse.

Briois, F., Manen, C., 2009. L'habitat néolithique ancien de Peiro Signado à Portiragnes (Hérault). In: Beeching, A., Sénépart, I. (Eds.), De la maison au village: l'habitat néolithique dans le Sud de la France et le Nord-Ouest méditerranéen. Société préhistorique française, Paris, pp. 31-37.

Briois, F., Vaquer, J., 2009. L'abri de Buholoup: de l'Épipaléolithique au Néolithique ancien dans le piedmont central des Pyrénées. In: Collectif (Ed.), De Méditerranée et d'ailleurs...: mélanges offerts à Jean Guilaine. Archives d'Ecologie préhistorique, Toulouse, pp. 141-149.

Carozza, J.-M., Valette, P., Carozza, L., Llubes, M., Ferdinand, L., Edou Obame, S. Sévègnes, L., 2013. L'architecture morpho-sédimentaire de la basse plaine de la Garonne moyenne en aval de Toulouse : premiers résultats. Quaternaire 24 $397-406$.

Coulonges, L., 1935. Les Gisements préhistoriques de Sauveterre-la-Lémance (Lotet-Garonne). Masson, Paris.

Crombé, P., Robinson, E., 2014. 14C dates as demographic proxies in Neolithisation models of northwestern Europe: a critical assessment using Belgium and northeast France as a case-study. J. Archaeol. Sci. 52, 558-566.

Dachary, M., Merlet, J.-C., Miquéou, M., Mallye, J.-B., Le Gall, O., Eastham, A., 2013. Les occupations mésolithiques de Bourrouilla à Arancou (Pyrénées-atlantiques, France). Paléo 24, 79-102.

Defranould, E., Caro, J., Perrin, T., Bobœuf, M., Manen, C., 2017. Mesolithic and Neolithic material productions in Aveyron (France) during the 6th millennium BC : originality or adaptability. In: Garciá-Martínez de Lagrán, I., LópezMontalvo, E., Manen, C. (Eds.), Contexts without Definition, Definition without Context. Arguments for the Characterization of the (Pre)Historic Realities during the Neolithisation of the Western Mediterranean, Proceedings of the XVIIth World UISPP Congress (1-7 Sept. 2014, Burgos), Session B20. Quaternary International. http://doi.org/10.1016/j.quaint.2017.01.036.

Dumontier, P. Courtaud, P. Ferrier, C., Armand, D., Mai, B.T., Convertini, F. Valdeyron, N., 2016. La grotte d'Apons à Sarrance (Pyrénées-Atlantiques). Des derniers chasseurs cueilleurs aux premières sociétés agro-pastorales en vallée
d'Aspe (8e au 2e millénaire avant notre ère). Préhistoire Du. Sud-Ouest 138.

Escalon de Fonton, M., 1966. Du Paléolithique supérieur au Mésolithique dans le Midi méditerranéen. Bull. Soc. préhist. fr. 63, 66-180.

Escalon de Fonton, M., 1968. Informations archéologiques, circonscription de Languedoc-Roussillon. fre 11, pp. 463-492.

Escalon de Fonton, M., 1971. La stratigraphie du gisement préhistorique de la Baume de Montclus (Gard). Mélanges de préhistoire, d'archéocivilisation et d'ethnologie offerts à André Varagnac. SEVPEN, Paris, pp. 263-278.

Fortea Pérez, F.J., 1973. Los complejos microlaminares y geometricos de Epipaleolitico mediterraneo espanol. Universidada de Salamanca, Salamanca.

García-Martínez de Lagrán, I., 2017. Review of the archaeological contexts and theoritical models of the Neolithisation of Spain: the North Meseta, the Ebro Walley and Catalonia as a case study. In: Garciá-Martínez de Lagrán, I., LópezMontalvo, E., Manen, C. (Eds.), Contexts without Definition, Definition without Context. Arguments for the Characterization of the (Pre)Historic Realities during the Neolithisation of the Western Mediterranean, Proceedings of the XVIIth World UISPP Congress (1-7 Sept. 2014, Burgos), Session B20. Quaternary International. http://doi.org/10.1016/j.quaint.2016.12.043.

Geddès, D., 1993. La faune de l'abri de Dourgne : paléontologie et paléoéconomie. In: Guilaine, J., Barbaza, M. Gascó, J. Geddès, D., Coularou, J. Vaquer, J. Brochier, J.É., Briois, F., André, J., Jalut, G., Vernet, J.-L. (Eds.), Dourgne: derniers chasseurs-collecteurs et premiers éleveurs de la Haute-Vallée de l'Aude. Centre d'Anthropologie des Sociétés rurales/Archéologie en Terre d'Aude, Toulouse/ Carcassonne, pp. 365-397.

Guilaine, J., 1979. L'abri Jean Cros: essai d'approche d'un groupe humain du Néolithique ancien dans son environnement. Centre d'anthropologie des sociétés rurales, Toulouse.

Guilaine, J., 1986. Le Néolithique ancien en Languedoc et Catalogne. In: Demoule, J.P., Guilaine, J. (Eds.), Le Néolithique de la France. Hommage à Gérard Bailloud. Picard, Paris, pp. 71-82.

Guilaine, J., 2013. The Neolithic Transition in Europe: some comments on gaps, contacts, arrhythmic model, genetics. In: Starnini, E. (Ed.), Unconformist Archaeology: Papers in Honour of Paolo Biagi. Archaeopress, Oxford, pp. 55-64.

Guilaine, J., Barbaza, M., Gascó, J., 1993. Dourgne: derniers chasseurs-collecteurs et premiers éleveurs de la Haute-Vallée de l'Aude. Centre d'Anthropologie des Sociétés rurales/Archéologie en Terre d'Aude, Toulouse/Carcassonne.

Guilaine, J., Manen, C., 2007. From Mesolithic to early Neolithic in the western Mediterranean. In: Whittle, A., Cummings, V. (Eds.), Going over: the Mesolithicneolithic Transition in North-West Europe. Oxford University Press, Oxford, pp. $21-51$.

Guilaine, J., Manen, C., Vigne, J.-D., 2007. Pont de Roque-Haute: nouveaux regards sur la néolithisation de la France méditerranéenne. Archives d'Ecologie Préhistorique, Toulouse.

Juan Cabanilles, J., García Puchol, O., 2013. Rupture et continuité dans la néolithisation du versant méditerranéen de la péninsule Ibérique : mise à l'épreuve du modèle de dualité culturelle. In: Jaubert, J., Fourment, N., Depaepe, P. (Eds.), Transitions, ruptures et continuité en Préhistoire, Évolution des techniques - Comportements funéraires - Néolithique ancien, vol. 1. Société préhistorique française, Paris, pp. 405-417.

Lacam, R., Niederlender, A., Vallois, H.V., 1944. Le gisement mésolithique du Cuzoul de Gramat. Masson, Paris.

Manen, C., 2014. Dynamiques spatio-temporelles et culturelles de la néolithisation ouest-méditerranéenne. In: Manen, C., Perrin, T., Guilaine, J. (Eds.), La transition néolithique en Méditerranée. Errance/Archives d'Ecologie préhistorique, Arles/ Toulouse, pp. 405-418.

Manen, C., Convertini, F., 2012. Neolithization of the Western Mediterranean: pottery productions, circulation and recombination. In: Borrell, M., Borrell Tena, F. Bosch Argilagós, J., Clop Garcia, X., Molist Montaña, M. (Eds.), Actes : Xarxes al Neolític : Congrés Internacional : Xarxes al neolític. Circulació i intercanvi de matèries, productes i idees a la Mediterránia occidental (VII-III mil.lenni aC). Museu de Gavà, Gavà, pp. 363-368.

Manen, C. Guilaine, J., 2010. Aspects géographiques et chronoculturels du Néolithique ancien languedocien. Premières Soc. paysannes Méditerr. Occident. Struct. Prod. Céram. 179-189.

Manen, C., Sabatier, P., 2003. Chronique radiocarbone de la néolithisation en Méditerranée nord-occidentale. Bull. Soc. préhist. fr. 100, 479-504.

Marchand, G., 1999. La Néolithisation de l'ouest de la France : caractérisation des industries lithiques. British archaeological Reports, Oxford.

Mazurié de Keroualin, K., 2003. Genèse et Diffusion de l'agriculture en Europe Agriculteurs, Chasseurs, Pasteurs. Errance, Paris.

Nicod, P.-Y., Perrin, T., Brochier, J.L., Chaix, L., Marquebielle, B., Picavet, R., Van Nieuwenhuyse, D., 2012. Continuités et ruptures culturelles entre chasseurs mésolithiques et chasseurs néolithiques en Vercors, analyse préliminaire des niveaux du Mésolithique récent et du Néolithique ancien sans céramique de l'abri-sous-roche de la Grande Rivoire (Sassenage, Isère). In: Perrin, T., Sénépart, I., Cauliez, J., Thirault, E., Bonnardin, S. (Eds.), Dynamismes et rythmes évolutifs des sociétés de la Préhistoire récente. Actualité de la recherche : Actes des 9e Rencontres Méridionales de Préhistoire Récente, Saint-Georges-deDidonne (17) - 8 \& 9 octobre 2010. Archives d'Ecologie Préhistorique, Toulouse, pp. 13-32.

Perrin, T., 2001. Évolution du silex taillé dans le Néolithique haut-rhodanien autour de la stratigraphie du Gardon (Ambérieu-en-Bugey, Ain). Presses Universitaires du Septentrion, Lille.

Perrin, T., 2005. Nouvelles réflexions sur la transition Mésolithique récent Néolithique ancien à l'abri Gaban (Trento, Italie). Preistoria Alpina. Rend. della 
Soc. Cult. Preisto. tridentina 41, 89-146.

Perrin, T. 2008. La néolithisation de la vallée du Rhône et de ses marges. In: Grimaldi, S., Perrin, T. (Eds.), Mountain Environments in Prehistoric Europe Settlement and Mobility Strategies from Palaeolithic to the Early Bronze Age. Archaeopress, Oxford, pp. 121-130.

Perrin, T., 2013. Potentialités de contacts entre mésolithiques et néolithiques dans le sud de la France. In: Jaubert, J., Fourment, N., Depaepe, P. (Eds.), Transitions, ruptures et continuité en Préhistoire, Évolution des techniques - Comportements funéraires - Néolithique ancien, vol. 1. Société préhistorique française, Paris, pp. 357-372.

Perrin, T., Manen, C., Séjalon, P., 2014. Le Néolithique ancien de la plaine de Nîmes (Gard, France). Archives d'Ecologie préhistorique/INRAP, Toulouse.

Perrin, T., Marchand, G., Valdeyron, N., Sam, B., 2017. D'un sens à l'autre et retour... La « flèche de Montclus » : un marqueur des interactions entre mésolithiques et néolithiques ? In: Jeunesse, C., Séara, F. (Eds.), Le second Mésolithique des Alpes à l'Atlantique (VIIe - Ve millénaires). Actes de la table ronde internationale de Strasbourg, 3-4novembre 2015. Société préhistorique française, Paris in press.

Puertas, O., 1999. Premiers indices polliniques de néolithisation dans la plaine littorale de Montpellier (Hérault, France). Bull. Soc. préhist. fr. 96, 15-20.

Reimer, P.J., Bard, E., Bayliss, A., Beck, J.W., Blackwell, P.G., Bronk Ramsey, C., Buck, C.E., Cheng, H., Edwards, R.L., Friedrich, M., Grootes, P.M., Guilderson, T.P., Haflidason, H., Hajdas, I., Hatté, C., Heaton, T.J., Hoffmann, D.L., Hogg, A.G., Hughen, K.A., Kaiser, K.F., Kromer, B., Manning, S.W., Niu, M., Reimer, R.W., Richards, D.A., Scott, E.M., Southon, J.R., Staff, R.A., Turney, C.S.M., Van der Plicht, J., 2013. IntCal13 and Marine13 radiocarbon age calibration curves 0-50,000 years cal BP. Radiocarbon 55, 1869-1887.

Roussot-Larroque, J., 1985. Sauveterre, et après. In: Otte, M. (Ed.), La signification culturelle des industries lithiques : actes du colloque de Liège, 3-7 octobre 1984. B.A.R., Oxford, pp. 170-205.

Roussot-Larroque, J. 1987. Les deux visages du Néolithique ancien d'Aquitaine. In: Guilaine, J., Courtin, J., Roudil, J.-L., Vernet, J.-L. (Eds.), Premières communautés paysannes en Méditerranée occidentale. Actes du colloque international du CNRS, Montpellier, 26-29 avril 1983. CNRS, Paris, pp. 681-691.

Rozoy, J.-G., 1971. Microburins et armatures microlithiques dans "le" Néolithique. Bull. Soc. préhist. fr. 68, 145-151.

Rozoy, J.-G., 1978. Les derniers chasseurs: l'Epipaléolithique en France et en
Belgique: essai de synthèse. Société archéologique champenoise, Reims.

Séronie-Vivien, M.-R., 2001. La grotte du Sanglier à Reilhac (Lot) : du Magdalénien au Néolithique ancien. Préhistoire du Sud-Ouest. Supplément 4. Préhistoire du Sud-Ouest, Cressensac.

Utrilla Miranda, P., Domingo Martinez, R., 2014. La transition MésolithiqueNéolithique dans la vallée de l'Ebre. In: Manen, C., Perrin, T., Guilaine, J. (Eds.) La transition néolithique en Méditerranée. Errance/Archives d'Ecologie préhistorique, Arles/Toulouse, pp. 327-358.

Valdeyron, N., 2000. Géographie culturelle du Mésolithique récent/final dans le sud-ouest de la France. In: Leduc, M., Valdeyron, N., Vaquer, J. (Eds.), Sociétés et espaces. Archives d'écologie préhistorique, Toulouse, pp. 23-34.

Valdeyron, N., Manen, C., Bosc-Zanardo, B., 2013. Mésolithique récent/final et néolithisation du sud-ouest de la France: vers de nouvelles perspectives ? In: Jaubert, J., Fourment, N., Depaepe, P. (Eds.), Transitions, ruptures et continuité en Préhistoire, Évolution des techniques - Comportements funéraires Néolithique ancien, vol. 1. Société préhistorique française, Paris, pp. 373-390.

Valdeyron, N., Bosc-Zanardo, B., Briand, T., Henry, A., Marquebielle, B., Michel, S. 2011. Le gisement du Cuzoul de Gramat (Lot, France): présentation des nouveaux travaux et résultats préliminaires. In: Sénépart, I., Perrin, T., Thirault, E., Bonnardin, S. (Eds.), Marges, frontières et transgressions. Actualité de la recherche. Actes des 8e Rencontres Méridionales de Préhistoire Récente, Marseille (13), 7-8 novembre 2008. Archives d'Ecologie Préhistorique, Toulouse, pp. 197-211.

Van Willigen, S., 2004. Aspects culturels de la néolithisation en Méditerranée occidentale : le Cardial et l'Epicardial. Bull. Soc. préhist. fr. 101, 463-495.

Vaquer, J., 1990. Le Néolithique en Languedoc Occidental. CNRS, Paris.

Vigne, J.-D., 2007. Exploitation des animaux et néolithisation en Méditerranée nordoccidentale. In: Guilaine, J., Manen, C., Vigne, J.-D. (Eds.), Pont de Roque-Haute: nouveaux regards sur la néolithisation de la France méditerranéenne. Archives d'Ecologie préhistorique, Toulouse, pp. 221-301.

Zilhão, J., 1993. The spread of agro-pastoral economies across Mediterranean Europe. A view from the Far West. J. Mediterr. Archaeol. 6, 5-63.

Zilhão, J., 2001. Radiocarbon evidence for maritime pioneer colonization at the origins of farming in west Mediterranean Europe. In: Proceedings of the National Academy of Sciences of the United States of America 98, Washington, pp. 14180-14185. 